\title{
Hypoxia-Triggered Self-Assembly of Ultra-Small Iron Oxide Nanoparticles to Amplify the Imaging Signal of Tumor
}

Huige Zhou ${ }^{1,4, \$}$, Mengyu Guo ${ }^{1,3, \$}$, Jiayang $\mathrm{Li}^{1,4, \$}$, Fenglan Qin ${ }^{1}$, Yuqing Wang ${ }^{1}$, Tao $\mathrm{Liu}^{1}$, Jing Liu ${ }^{1}$, Zeinab Farhadi Sabet ${ }^{1,3}$, Yaling Wang ${ }^{1,4,5}$, Ying Liu ${ }^{1,4,5}$, Qing Huo ${ }^{2}$, Chunying Chen ${ }^{1,3,4,5, *}$

1. CAS Key Laboratory for Biomedical Effects of Nanomaterials and Nanosafety and CAS Center for Excellence in Nanoscience, National Center for Nanoscience and Technology of China, Beijing 100190, China.

2. Department of Biomedical, College of Biochemical Engineering, Beijing Union University, Beijing 100023, China

3. University of Chinese Academy of Sciences, Beijing 100049, China.

4. Research Unit of Nanoscience and Technology, Chinese Academy of Medical Sciences, Beijing 100021, China

5. GBA Research Innovation Institute for Nanotechnology, Guangdong 510700, China 


\section{EXPERIMENTAL METHODS}

Chemical: 4-(Aminomethyl) piperidine (98\%), 4-Chloro-7-nitro-2,1,3-benzoxadiazole (NBD, 98\%), 1-ethyl-3-(3-dimethylaminopropyl) carbodiimide hydrochloride (EDC, 98\%) and N-Hydroxysuccinimide (NHS, 98\%) were purchased from TCI. Benzaldehyde (99.5\%), Fmoc-Lys-L-OH (98\%) and $\beta$-NADPH (95\%) were purchased from Aladdin. 1-(2,3-Epoxypropyl)-2-nitroimidazole (97\%), piperiddine $(99.5 \%)$ and nitroreductase were purchased from Sigma-Aldrich. N, N'-dicyclohexylcarbodiimide (DCC, 98\%) were purchased from fluorochem. L-Cysteine (Cys, 99\%) were purchased from Macklin. Polyacrylic acid (Mw = 2000Da, 63\%wt water solution) was purchased from Acros. The water used throughout the experiments was Millipore water (18.2 M $\Omega$ ). All of the chemicals were used as received without further purification.

\section{Characterization:}

HPLC analyses were performed on a Breeze 2 HPLC system equipped with a Binary HPLC pump (Waters 1525) and UV/Vis detector (Waters 2489) using a reverse-phase column (Waters, XBridge, OBD, $\mathrm{C} 18,5 \mu \mathrm{m}, 19 \mathrm{~mm} \times 250 \mathrm{~mm})$ with $\mathrm{CH}_{3} \mathrm{CN}(0.1 \%$ of trifluoroacetic acid (TFA)) and water $(0.1 \%$ of TFA $)$ as the eluent. Pekin-Elmer lambda 950 spectrophotometer was used to record the UV-Vis absorption and fluorescence spectra. Bruker AVANCE III HD 400 spectrometer was used to obtain ${ }^{1} \mathrm{H}$ NMR spectra. Solarix $9.4 \mathrm{~T}$ mass spectrometer (Bruker) was used to record the spectra of electrospray ionization-mass spectrometry (ESI-MS). TEM images were conducted with the Tecnai G2 20 S-TWIN electron microscope at an accelerating voltage of $200 \mathrm{kV}$. The concentration of Fe was observed and recorded by ICP-OES (PE8000, PerkinElmer). Dynamic light scattering (DLS) measurements were carried out with a Zeta Sizer Nano series Nano-ZS (Malvern Instruments Ltd). BioSpec 70/20USR 7.0 T (Bruker) was used to measure and record the $\mathrm{T}_{2}$ relaxation time and MRI images in vitro and in vivo.

\section{Synthesis:}




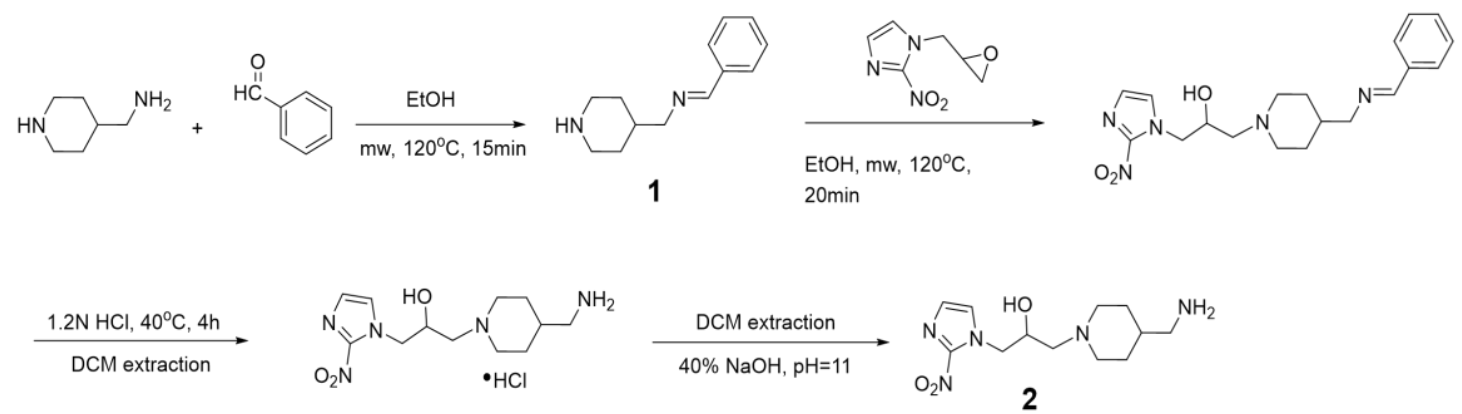

Scheme S1. Synthetic route of compound 2 (Pimonidazole- $\mathrm{NH}_{2}$ ).

\section{Compound 1}

Compound 1 was synthesized according to literature with little modification ${ }^{1}$. Briefly, 4-(Aminomethyl) piperidine $(1.48 \mathrm{~mL}, 12.3 \mathrm{mmol})$ and Benzaldehyde $(1.28 \mathrm{~mL}, 12.3 \mathrm{mmol})$ mixed in super dry ethanol (EtOH, $10 \mathrm{~mL}$ ). Then, the mixture was heated to $120^{\circ} \mathrm{C}$ in 10 minutes and kept at this temperature for 15 minutes under microwave condition. When the reaction system was cooled to room temperature, ethanol was evaporated and the residue was dried under vacuum overnight to obtain compound 1 as yellow oil ( $2.25 \mathrm{~g}, 84.7 \%)$, which wasused without further purification. ${ }^{1} \mathrm{H}$ NMR $(400 \mathrm{MHz}, \mathrm{MeOD}) \delta 8.30(\mathrm{~s}, 1 \mathrm{H}), 7.76-7.70(\mathrm{~m}, 2 \mathrm{H}), 7.49-7.39(\mathrm{~m}, 3 \mathrm{H})$, $3.50(\mathrm{~d}, J=6.6 \mathrm{~Hz}, 2 \mathrm{H}), 3.07(\mathrm{~d}, J=12.4 \mathrm{~Hz}, 2 \mathrm{H}), 2.62(\mathrm{td}, J=12.4,2.3 \mathrm{~Hz}, 2 \mathrm{H}), 1.87-1.67(\mathrm{~m}, 4 \mathrm{H})$, $1.35-1.08(\mathrm{~m}, 3 \mathrm{H}) . \mathrm{MS}$ : calculated for compound $1\left[(\mathrm{M}+\mathrm{H})^{+}\right]$: 217.16; observed ESI-MS: m/z 217.17.

\section{Compound 2}

Compound 2 was synthesized according to literature with little modification ${ }^{1}$. Briefly, compound 1 (357mg, $1.77 \mathrm{mmol}$ ) and 1-(2, 3-Epoxypropyl)-2-nitroimidazole (250 mg, $1.55 \mathrm{mmol})$ were mixed in super dry ethanol $(10 \mathrm{~mL})$ and heated at $120{ }^{\circ} \mathrm{C}$ for $20 \mathrm{~min}$. After cooling to room temperature, the reaction solution was concentrated to $1 \mathrm{~mL}$ by evaporation and mixed with $\mathrm{HCl}$ aqueous solution $(2 \mathrm{~mL}, 1.2 \mathrm{~N})$ at $40{ }^{\circ} \mathrm{C}$ for $4 \mathrm{~h}$. The reaction mixture was extracted with dichloromethane $(4 \times 12 \mathrm{~mL})$. Then, the water phase was adjusted to $\mathrm{pH} 11$ by $40 \%$ of $\mathrm{NaOH}$ aqueous solution and extracted with dichloromethane $(4 \times 14 \mathrm{~mL})$ until the primary amino cannot be detected by silica gel TLC analysis. The organic phase was demulsified by saturated sodium chloride aqueous solution and dried over anhydrous $\mathrm{MgSO}_{4}$. After filtration, the solvent was 
removed by evaporation, and the residue was dried under vacuum overnight to obtain compound 2 as yellow oil (285 mg, 65.0\%). ${ }^{1} \mathrm{H}$ NMR $(400 \mathrm{MHz}, \mathrm{MeOD}) \delta 7.48(\mathrm{~s}, 1 \mathrm{H}), 7.14(\mathrm{~s}, 1 \mathrm{H}), 4.78(\mathrm{dd}, J=$ 13.8, 3.2 Hz, 1H), $4.31(\mathrm{dd}, J=13.8,8.2 \mathrm{~Hz}, 1 \mathrm{H}), 4.18-4.08(\mathrm{~m}, 1 \mathrm{H}), 3.01(\mathrm{~d}, J=11.2 \mathrm{~Hz}, 1 \mathrm{H}), 2.91$ $(\mathrm{d}, J=11.1 \mathrm{~Hz}, 1 \mathrm{H}), 2.52(\mathrm{~d}, J=6.4 \mathrm{~Hz}, 2 \mathrm{H}), 2.49-2.35(\mathrm{~m}, 2 \mathrm{H}), 2.06(\mathrm{dd}, J=21.3,10.1 \mathrm{~Hz}, 2 \mathrm{H})$, $1.74(\mathrm{~d}, J=11.3 \mathrm{~Hz}, 2 \mathrm{H}), 1.42-1.15(\mathrm{~m}, 3 \mathrm{H})$. MS: calculated for compound $2\left[(\mathrm{M}+\mathrm{H})^{+}\right]: 284.16$; observed ESI-MS: m/z 284.17.
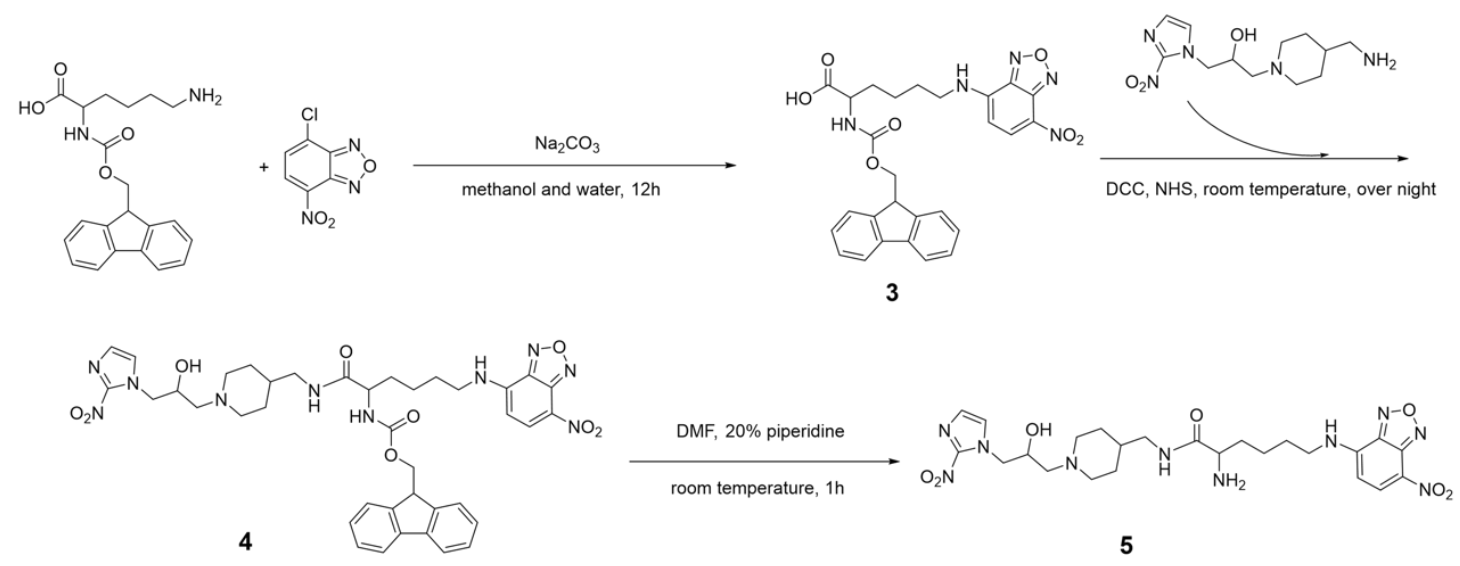

Scheme S2. Synthetic route of compound 5 (Pimo).

\section{Compound 3}

Fmoc-Lys-OH (184 mg, $0.5 \mathrm{mmol})$ and $\mathrm{NaCO}_{3}(139 \mathrm{mg}, 1 \mathrm{mmol})$ were dissolved in the mixture solution of methanol $(6.28 \mathrm{~mL})$ and water $(5 \mathrm{~mL})$, stirring for several minutes until the solution became clear. After that, $2 \mathrm{~mL}$ methanol solution of NBD (100 mg, $0.5 \mathrm{mmol})$ was added and stirred at room temperature for $12 \mathrm{~h}$. Then, methanol was removed by evaporating and the water phase was adjusted to $\mathrm{pH} 2 \sim 3$ by $\mathrm{HCl}$ aqueous solution $(1 \mathrm{~N})$. After centrifugation $(9500 \mathrm{rpm} \times 5$ min), the supernate was removed and the precipitation was washed with water three times to adjust the $\mathrm{pH}$ to neutral. Then, the precipitation was further purified with HPLC using water-acetonitrile added with $0.1 \%$ TFA as the eluent (from 20:80 to 0:100) to obtain compound 3 (65.8mg, yield: 24.8\%). ${ }^{1} \mathrm{H}$ NMR (400 MHz, MeOD) $\delta 8.43(\mathrm{~d}, J=8.4 \mathrm{~Hz}, 1 \mathrm{H}), 7.76(\mathrm{~d}, J=7.4 \mathrm{~Hz}$, 2H), $7.64(\mathrm{dd}, J=12.2,7.6 \mathrm{~Hz}, 2 \mathrm{H}), 7.36(\mathrm{~s}, 2 \mathrm{H}), 7.28(\mathrm{dd}, J=14.3,7.1 \mathrm{~Hz}, 2 \mathrm{H}), 6.27(\mathrm{~d}, J=8.8 \mathrm{~Hz}$, $1 \mathrm{H}), 4.50-4.34(\mathrm{~m}, 1 \mathrm{H}), 4.34-4.26(\mathrm{~m}, 1 \mathrm{H}), 4.26-4.13(\mathrm{~m}, 2 \mathrm{H}), 3.50(\mathrm{~s}, 2 \mathrm{H}), 2.05-1.67(\mathrm{~m}, 4 \mathrm{H})$, $1.67-1.49(\mathrm{~m}, 2 \mathrm{H})$. MS: calculated for compound $3[(\mathrm{M}-\mathrm{H})]$ : 530.18; observed ESI-MS: m/z: 530.17 . 


\section{Compound 4}

Compound 3 (50 mg, $0.094 \mathrm{mmol})$ and NHS (11 mg, $0.094 \mathrm{mmol})$ were dissolved in dichloromethane $(2 \mathrm{~mL})$. DCC $(23.2 \mathrm{mg}, 0.1128 \mathrm{mmol})$ was added to the reaction and stirred at room temperature for 3 hours. Then, the precipitation was removed by filtration and dichloromethane was evaporated. The residue and compound 2 (26.6 $\mathrm{mg}, 0.094 \mathrm{mmol})$ were dissolved in dimethylformamide $(2 \mathrm{~mL})$ and stirred at room temperature for $12 \mathrm{~h}$. DMF was removed by blowing nitrogen and the residue was dissolved in the mix solution of water and methanol for HPLC purification to obtain compound $4 .{ }^{1} \mathrm{H}$ NMR $(400 \mathrm{MHz}, \mathrm{MeOD}) \delta 8.48(\mathrm{~d}, J=$ $8.7 \mathrm{~Hz}, 1 \mathrm{H}), 7.80(\mathrm{~d}, J=7.3 \mathrm{~Hz}, 2 \mathrm{H}), 7.65(\mathrm{~d}, J=9.1 \mathrm{~Hz}, 2 \mathrm{H}), 7.48(\mathrm{~s}, 1 \mathrm{H}), 7.39$ (td, $J=7.7,2.6 \mathrm{~Hz}$, 2H), $7.31(\mathrm{dd}, J=14.0,7.1 \mathrm{~Hz}, 2 \mathrm{H}), 7.20(\mathrm{~s}, 1 \mathrm{H}), 6.32(\mathrm{~d}, J=8.8 \mathrm{~Hz}, 1 \mathrm{H}), 4.66(\mathrm{~d}, J=10.5 \mathrm{~Hz}, 1 \mathrm{H})$, $4.50-4.35(\mathrm{~m}, 2 \mathrm{H}), 4.34-4.13(\mathrm{~m}, 3 \mathrm{H}), 4.11-3.97$ (m, 1H), 3.57 (s, 2H), $3.52-3.40(\mathrm{~m}, 2 \mathrm{H}), 3.25-$ $2.84(\mathrm{~m}, 4 \mathrm{H}), 1.92-1.78(\mathrm{~m}, 7 \mathrm{H}), 1.79-1.66(\mathrm{~m}, 6 \mathrm{H})$. MS: calculated for compound 4 [(M-H)]: 795.33; observed ESI-MS: m/z: 795.32.

\section{Compound 5}

Compound 4 (20 mg, $0.026 \mathrm{mmol})$ was dissolved in DMF (2 mL) containing piperidine (20\%, $\mathrm{V} / \mathrm{V}$ ) and stirred at room temperature for $1 \mathrm{~h}$. The end of this reaction was confirmed by TLC plate staining with ninhydrin ( $2 \%$ of alcohol solution). Then, DMF was removed by blowing nitrogen and the residue was dissolved in the mix solution of water and methanol for HPLC purification to obtain compound 5 (Pimo). ${ }^{1} \mathrm{H}$ NMR (400 MHz, MeOD, Figure S1) $\delta 8.53(\mathrm{~d}, J=8.8 \mathrm{~Hz}, 1 \mathrm{H}), 7.50$ (s, 1H), $7.20(\mathrm{~s}, 1 \mathrm{H}), 6.36(\mathrm{~d}, J=8.8 \mathrm{~Hz}, 1 \mathrm{H}), 4.68(\mathrm{~d}, J=12.2 \mathrm{~Hz}, 1 \mathrm{H}), 4.51-4.32(\mathrm{~m}, 2 \mathrm{H}), 3.87(\mathrm{t}, J$ $=6.1 \mathrm{~Hz}, 1 \mathrm{H}), 3.66(\mathrm{~d}, J=11.9 \mathrm{~Hz}, 2 \mathrm{H}), 3.60(\mathrm{~s}, 2 \mathrm{H}), 3.26-2.78(\mathrm{~m}, 4 \mathrm{H}), 2.17-1.71(\mathrm{~m}, 7 \mathrm{H}), 1.68-$ $0.64(\mathrm{~m}, 6 \mathrm{H})$. MS: calculated for compound $5\left[(\mathrm{M}+\mathrm{H})^{+}\right]$: 575.26; observed ESI-MS: m/z: 575.27 (Figure S2). 


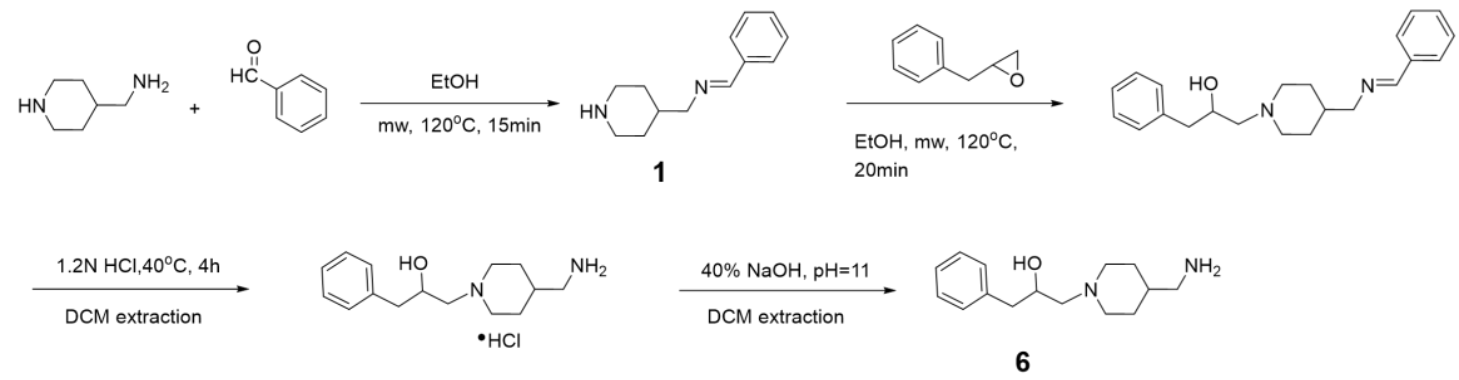

Scheme S3. Synthetic route of compound 6.

\section{Compound 6}

Compound 6 was synthesized as the same way of compound 2 except to change the 1-(2, 3-Epoxypropyl)-2-nitroimidazole (250 mg, $1.55 \mathrm{mmol}$ ) with (2, 3-Epoxypropyl)-benzene (208 mg, $1.55 \mathrm{mmol}) .{ }^{1} \mathrm{H}$ NMR $(400 \mathrm{MHz}, \mathrm{MeOD}) \delta 7.33-7.10(\mathrm{~m}, 5 \mathrm{H}), 4.04-3.90(\mathrm{~m}, 1 \mathrm{H}), 2.94(\mathrm{dd}, \mathrm{J}=$ 10.0, 9.1 Hz, 2H), $2.69(\mathrm{dd}, \mathrm{J}=20.5,18.7 \mathrm{~Hz}, 2 \mathrm{H}), 2.49(\mathrm{~d}, \mathrm{~J}=6.4 \mathrm{~Hz}, 2 \mathrm{H}), 2.36(\mathrm{~d}, \mathrm{~J}=6.0 \mathrm{~Hz}$, 2H), $2.02(\mathrm{dt}, \mathrm{J}=53.6,11.7 \mathrm{~Hz}, 2 \mathrm{H}), 1.71(\mathrm{~d}, \mathrm{~J}=11.4 \mathrm{~Hz}, 2 \mathrm{H}), 1.42-1.10(\mathrm{~m}, 3 \mathrm{H}) . \mathrm{MS}$ : calculated for compound $6\left[(\mathrm{M}+\mathrm{H})^{+}\right]: 249.19$; observed. ESI-MS: m/z: 249.20.
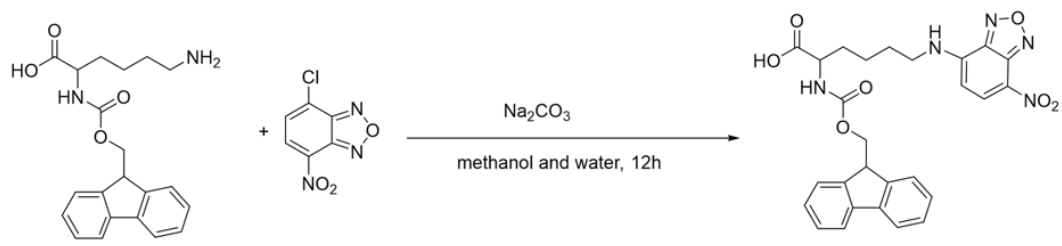

3
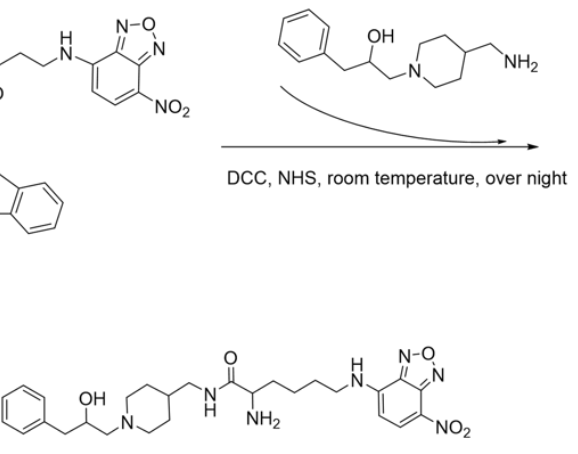

8

Scheme S4. Synthetic route of compound 8 (B).

\section{Compound 7}

Compound 7 was synthesized as the same procedure of compound 4 except changing compound 2 with compound 6. ${ }^{1} \mathrm{H}$ NMR $(400 \mathrm{MHz}, \mathrm{MeOD}) \delta 8.48(\mathrm{~d}, J=8.9 \mathrm{~Hz}, 1 \mathrm{H}), 7.79(\mathrm{dd}, J=7.1,4.4 \mathrm{~Hz}$, 2H), $7.65(\mathrm{dd}, J=7.1,3.7 \mathrm{~Hz}, 2 \mathrm{H}), 7.50-7.18(\mathrm{~m}, 9 \mathrm{H}), 6.32(\mathrm{~d}, J=8.8 \mathrm{~Hz}, 1 \mathrm{H}), 4.44(\mathrm{dd}, J=10.4$, $6.5 \mathrm{~Hz}, 1 \mathrm{H}), 4.33-4.12(\mathrm{~m}, 3 \mathrm{H}), 4.09-3.99(\mathrm{~m}, 1 \mathrm{H}), 3.66-3.44(\mathrm{~m}, 4 \mathrm{H}), 3.17-2.90(\mathrm{~m}, 4 \mathrm{H}), 2.88-$ $2.74(\mathrm{~m}, 2 \mathrm{H}), 2.02-1.65(\mathrm{~m}, 7 \mathrm{H}), 1.65-1.16(\mathrm{~m}, 6 \mathrm{H})$. MS: calculated for compound 7 [(M-H) $]$ : 
760.35; observed. ESI-MS: m/z:760.35.

\section{Compound 8}

Compound 8 (B) was synthesized with the same way of compound 5 except changing compound 4 by compound 7 (18mg, $0.033 \mathrm{mmol}) .{ }^{1} \mathrm{H}$ NMR $(400 \mathrm{MHz}, \mathrm{MeOD}$, Figure S3) $\delta 8.54(\mathrm{~d}, J=8.9 \mathrm{~Hz}$, 1H), $7.44-7.17(\mathrm{~m}, 5 \mathrm{H}), 6.37(\mathrm{~d}, J=8.8 \mathrm{~Hz}, 1 \mathrm{H}), 4.26(\mathrm{~d}, J=4.3 \mathrm{~Hz}, 1 \mathrm{H}), 3.86(\mathrm{t}, J=6.2 \mathrm{~Hz}, 1 \mathrm{H})$, $3.74-3.43(\mathrm{~m}, 4 \mathrm{H}), 3.22-2.95(\mathrm{~m}, 4 \mathrm{H}), 2.91-2.76(\mathrm{~m}, 2 \mathrm{H}), 2.07-1.63(\mathrm{~m}, 7 \mathrm{H}), 1.61-0.81(\mathrm{~m}$, 6H). MS: calculated for compound 8 [(M-H) $]$ ]: 538.29; observed. ESI-MS: m/z: 538.28 (Figure S4).
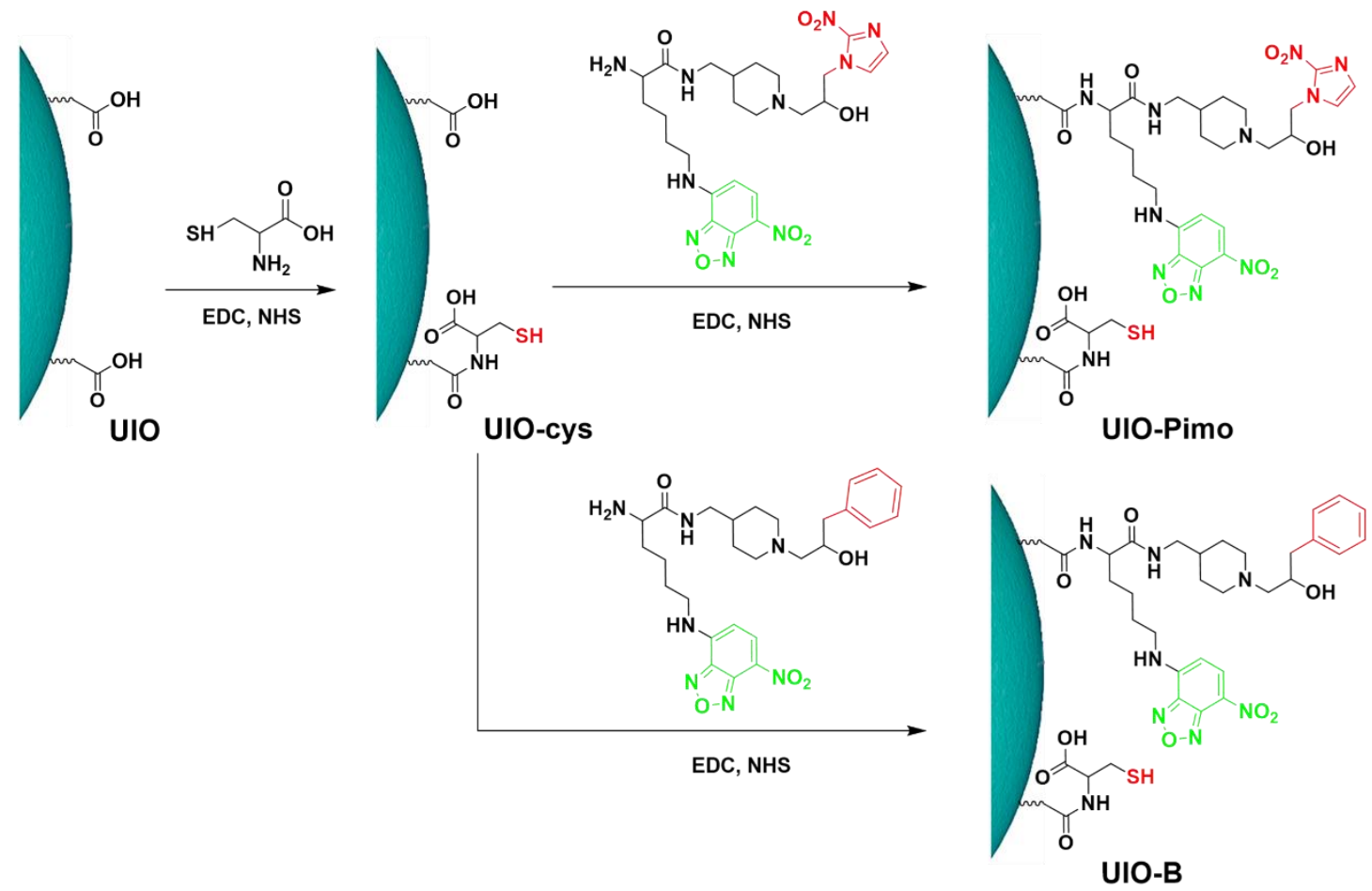

Scheme S5. Synthetic route of the UIO-Pimo and UIO-B.

\section{UIO}

$\mathrm{Fe}_{3} \mathrm{O}_{4} @ \mathrm{PAA}$ (UIO) was synthesized according to literature ${ }^{2}$. Briefly, PAA $\left(0.147 \mathrm{~g},\left[\mathrm{COO}^{-}\right]=2.04\right.$ mmol) was dissolved in $50 \mathrm{~mL}$ water and the temperature was risen to $102{ }^{\circ} \mathrm{C}$ by oil bath while purged with nitrogen for $0.5 \mathrm{~h}$. At the same time, $\mathrm{FeCl}_{3} \cdot 6 \mathrm{H}_{2} \mathrm{O}(0.1459 \mathrm{~g}, 0.54 \mathrm{mmol})$ and $\mathrm{FeCl}_{2} \cdot 4 \mathrm{H}_{2} \mathrm{O}(0.0715 \mathrm{~g}, 0.36 \mathrm{mmol})$ were dissolved in dilute $\mathrm{HCl}$ solution $(2 \mathrm{~mL}, 1.0 \mathrm{M})$. The iron 
ion solution was quickly injected into the hot PAA solution under a nitrogen atmosphere with vigorous stirring. Ammonia solution $(15 \mathrm{~mL}, 28 \%)$ was injected within 5 seconds. The reaction mixture was refluxed for $40 \mathrm{~min}$ and then cooled to room temperature and dialyzed for $72 \mathrm{~h}$ in a Spectra/Por (MWCO: 12000-14000) dialysis bag against deionized water (eight exchanges) to remove unreacted reagents. The content of the dialysis bag was concentrated by evaporation and filtered through a $0.22 \mu \mathrm{m}$ filter membrane to collect in a glass bottle.

\section{UIO-Pimo and UIO-B}

UIO (1.6 mg Fe in $0.32 \mathrm{~mL}$ water) was dissolved in $4 \mathrm{~mL}$ MES buffer (pH 6.0, $50 \mathrm{mM}$ ). $0.25 \mathrm{~mL}$ MES buffer containing EDC $(15.2 \mathrm{mg}, 80 \mu \mathrm{mol})$ and NHS $(9.2 \mathrm{mg}, 80 \mu \mathrm{mol})$ was added to activate the carboxyl group on the surface of UIO. After $2 \mathrm{~h}$ stirring at room temperature, those unreacted agents were removed by $10 \mathrm{~K}$ ultrafiltration tube (Milli-Q) at $6000 \mathrm{rpm} / \mathrm{min} \times 20 \mathrm{~min}$ and washed with deionized water thrice. The upper nanoparticle solution was re-dispersed in water $(4 \mathrm{~mL})$ and Cys $(9.6 \mathrm{mg}, 0.08 \mathrm{mmol})$ was added. The reaction was left at room temperature for 24 $\mathrm{h}$, and then the excess Cys was also removed by ultrafiltration and the filtrate solution was collected to measure the reaction efficiency through the DTNB method ${ }^{3}$. After the nanoparticle solution was re-activated by EDC/NHS in the same way described above, it was re-dispersed in PBS (4 mL, pH 7.4) and hypoxia ligand Pimo $(574 \mu \mathrm{g}, 1 \mu \mathrm{mol})$ or the control ligand (B) was added. After stirring at room temperature for $24 \mathrm{~h}$, the unreacted Pimo (or B) was removed by ultrafiltration to obtain UIO-Pimo (or UIO-B) and the filtrate solution was collected to detect the absorbance at $480 \mathrm{~nm}$ to obtain the reaction efficiency.

\section{Hypoxia response:}

\section{Molecular level}

Pimo $(57.3 \mu \mathrm{g}, 0.1 \mu \mathrm{mol})$ and Cys $(0.2 \mathrm{mg}, 1.65 \mu \mathrm{mol})$ were dissolved in PBS buffer $(1 \mathrm{~mL}, \mathrm{pH}$ 7.4) in an EP tube $(10 \mathrm{~mL})$. The tube was put at $37{ }^{\circ} \mathrm{C}$ and bubbled with argon for 10 minutes. Then, argon flow was stopped, the PBS solution of NADPH $(2 \mathrm{mg} / \mathrm{mL}, 0.1 \mathrm{~mL})$ and nitroreductase $(0.1 \mathrm{mg} / \mathrm{mL}, 0.1 \mathrm{~mL})$ were injected into the tube, respectively. Then argon was re-started to bubble for 30 minutes. After that, argon flow was stopped and the tube was sealed by 
parafilm to put at $37{ }^{\circ} \mathrm{C}$ overnight. The hypoxia reaction of B and Cys was conducted in the same way. HPLC and ESI-MS were used to detect the adduct.

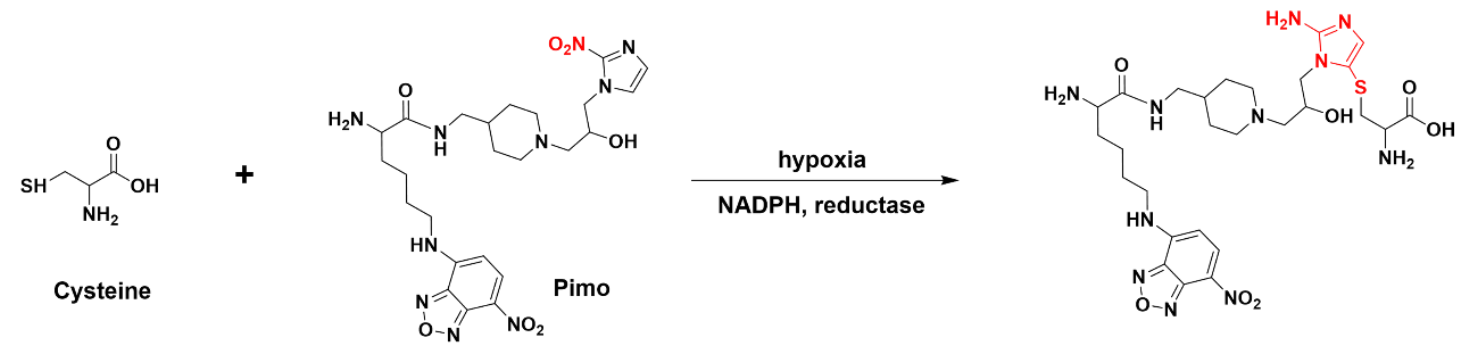

Scheme S6. Illustration of the hypoxia reaction between L-Cysteine and Pimo under NADPH and nitroreductase.

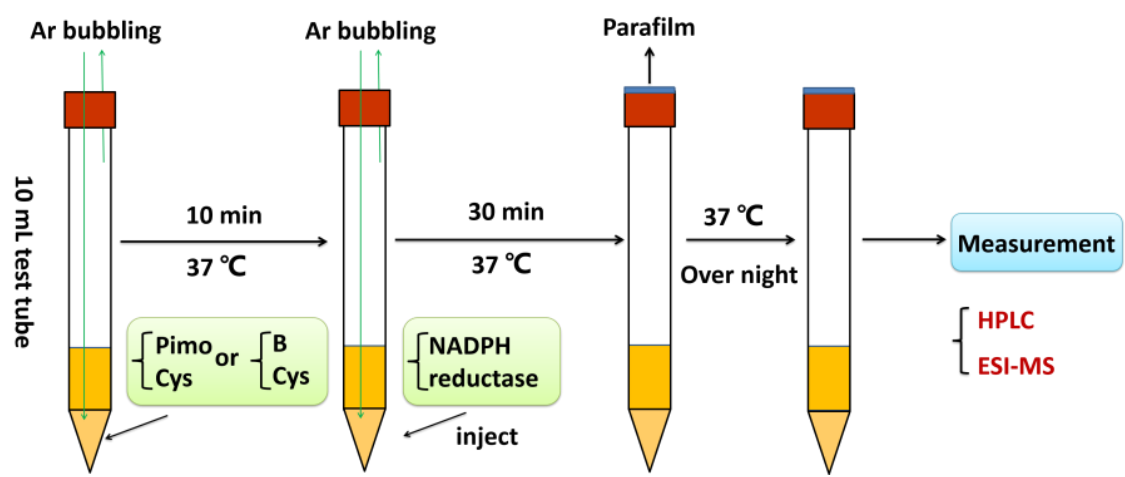

Scheme S7. Illustration of L-Cysteine (Cys) and Pimo under hypoxia with the existence of NADPH and nitroreductase.

\section{Nanoparticle level}

UIO-Pimo or UIO-B $(25 \mu \mathrm{g} \mathrm{Fe})$ was dispersed in PBS buffer $(1 \mathrm{~mL}, \mathrm{pH} 7.4)$ in an EP tube (10 $\mathrm{mL}$ ). The tube was put at $37^{\circ} \mathrm{C}$ and bubbled with argon for 10 minutes. Then, argon flow was stopped, NADPH $(5 \mathrm{mg} / \mathrm{mL}, 0.1 \mathrm{~mL})$ and nitroreductase $(0.1 \mathrm{mg} / \mathrm{mL}, 0.1 \mathrm{~mL})$ were injected into the tube, and argon was re-started to bubble for $60 \mathrm{~min}$. If the demand time is above $1 \mathrm{~h}$, tubes were sealed by the parafilm and put at $37{ }^{\circ} \mathrm{C}$ for the defined time (the same as Scheme S7). After the above operation, the nanoparticle solution was collected to detect the hydration size, TEM morphology, MRI signal and fluorescence intensity. MRI data were recorded with the following parameters: $\mathrm{TR}=3000 \mathrm{~ms}, \mathrm{TE}=40 \mathrm{~ms}$, echo time $=66 \mathrm{~ms}$, field of view $=70 \times 70 \mathrm{~mm}$, matrix size $=256 \times 256$, number of slices $=16$, slice thickness $=1 \mathrm{~mm}$, flip angle $=90^{\circ}$. 

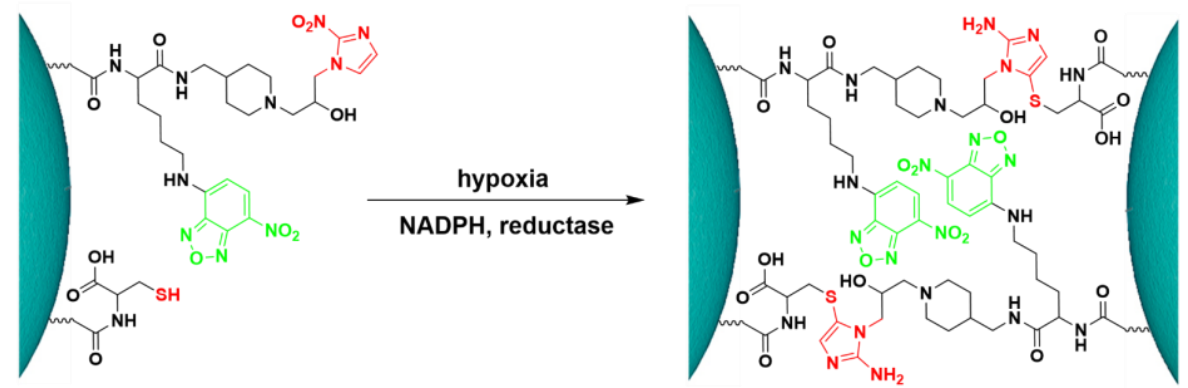

Scheme S8. Illustration of the hypoxia reaction of UIO-Pimo under NADPH and nitroreductase.

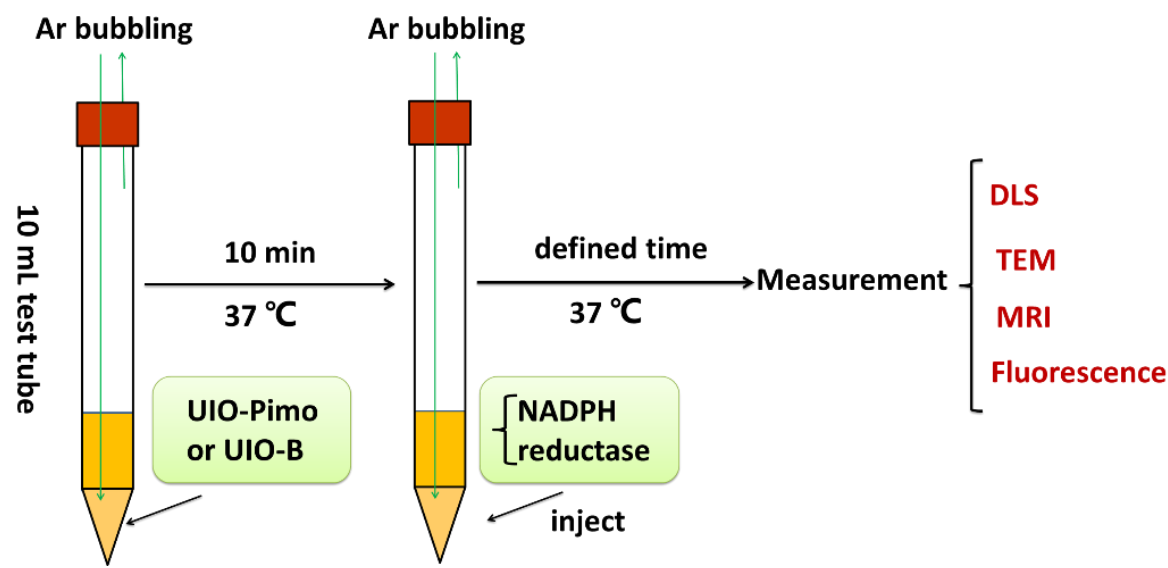

Scheme S9. Illustration of UIO-Pimo under hypoxia with the existence of NADPH and nitroreductase.

\section{The influence of GSH}

UIO-Pimo $(40 \mu \mathrm{g} \mathrm{Fe})$ and a certain amount of GSH were dispersed in PBS buffer (1 mL, pH 7.4) in an EP tube $(10 \mathrm{~mL})$. The tube was put at $37^{\circ} \mathrm{C}$ and bubbled with argon for 10 minutes. Then, argon flow was stopped, NADPH $(5 \mathrm{mg} / \mathrm{mL}, 0.1 \mathrm{~mL})$ and nitroreductase $(0.1 \mathrm{mg} / \mathrm{mL}, 0.1 \mathrm{~mL})$ were injected into the tube, and argon was re-started to bubble for $60 \mathrm{~min}$. After the above operation, the nanoparticle solution was collected to detect the hydration size and TEM morphology. MRI data were recorded with the following parameters: $\mathrm{TR}=3000 \mathrm{~ms}$, $\mathrm{TE}=40 \mathrm{~ms}$, echo time $=66 \mathrm{~ms}$, field of view $=70 \times 70 \mathrm{~mm}$, matrix size $=256 \times 256$, number of slices $=16$, slice thickness $=1 \mathrm{~mm}$, flip angle $=90^{\circ}$. 


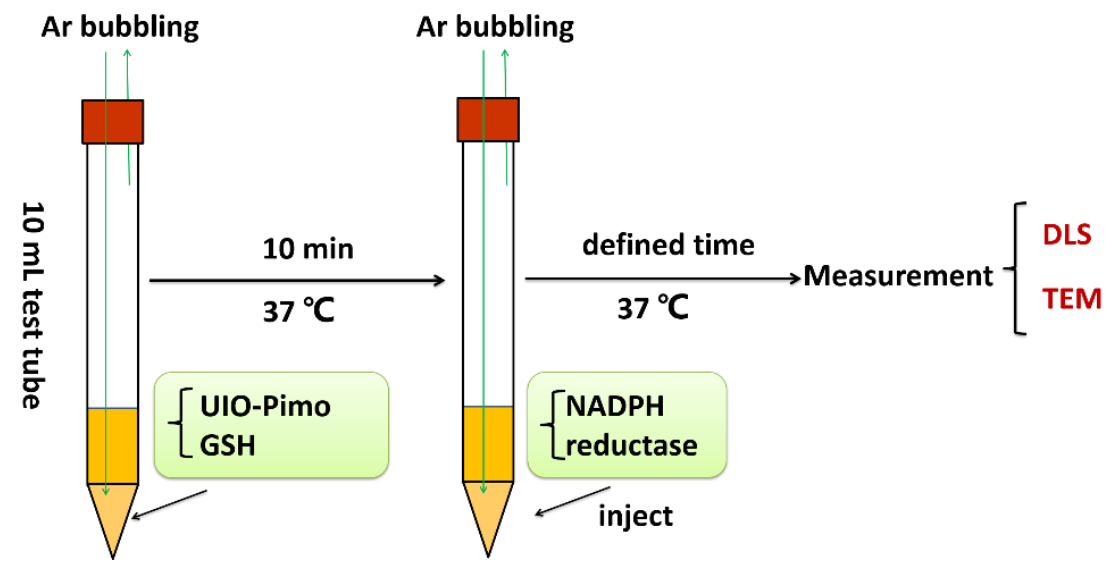

Scheme S10. Illustration of UIO-Pimo under hypoxia with the co-existence of GSH, NADPH and reductase.

\section{In vitro and in vivo experiments}

\section{Cell lines and animals}

MDA-MB-231 cells (human breast cancer cell), 4T1 cells (mouse breast cancer cell), MCF-7 cells (human breast cancer cell) and B16 cells (mouse melanoma cell) were obtained from the Cell Bank of Chinese Academy of Science (Shanghai, China). MDA-MB-231 cells and MCF-7 cells were cultured in Dulbecco's Modified Eagle Medium (DMEM) and 4T1 cells and B16 cells were cultured in Roswell Park Memorial Institute Medium (RPMI 1640), which were all supplemented with $10 \%$ fetal bovine serum (FBS) and $1 \%$ penicillin/streptomycin at $37{ }^{\circ} \mathrm{C}$ in $100 \%$ humidity and $5 \% \mathrm{CO}_{2}$. BALB/c mice (female, 6 weeks age, and 16-18 g body weight) were obtained from Vital River Laboratory Animal Technology Co., Ltd. (Beijing, China) and housed with a $12 \mathrm{~h}$ light-dark cycle at $22{ }^{\circ} \mathrm{C}$ and food and water ad libitum. All animal protocols were approved by the Institutional Animal Care and Use Committee of National Center for Nanoscience and Technology. The breast tumor model was established by subcutaneously transplanting 4T1 cells (1 $\times 10^{6}$ cells each) into the right fat pad of each mouse.

\section{In vitro cytotoxicity}

MDA-231 cells, 4T1 cells, MCF-7 cells and B16 cells were incubated with UIO, UIO-B and UIO-Pimo and cell cytotoxicity was evaluated using the CCK- 8 kit, according to the manufacturer's instructions. Briefly, 5000 cells per well were treated with UIO, UIO-B and UIO-Pimo at $72 \mu \mathrm{g} \mathrm{Fe} / \mathrm{mL}$ for $24 \mathrm{~h}$. Then, $100 \mu \mathrm{l}$ per well of $10 \%$ CCK-8 solution was added to 
the cells and incubated at $37{ }^{\circ} \mathrm{C}$ for $1 \mathrm{~h}$. An ELISA microplate reader was used to read the absorbance of the CCK-8 solution at $450 \mathrm{~nm}$ (excitation)/600 nm (emission).

\section{Fluorescence imaging of UIO-Pimo.}

MDA-MB-231 cells seeded in 6-well plates $\left(6 \times 10^{5}\right.$ cells per well) were treated with $30 \mu \mathrm{M}$ UIO-Pimo and UIO-B at different oxygen concentrations $\left(0.1 \% \mathrm{O}_{2}, 2 \% \mathrm{O}_{2}\right.$ and $\left.21 \% \mathrm{O}_{2}\right)$ for $3 \mathrm{~h}$ at $37^{\circ} \mathrm{C}$. Before being treated with UIO-Pimo and UIO-B, MDA-MB-231 cells were precultured in the hypoxic incubator for about 12 hours. At the end of incubation, cells were washed with PBS thrice and, then stained with DAPI and resuspended in $0.5 \mathrm{~mL}$ of PBS. The intracellular fluorescence of UIO-Pimo and UIO-B was determined by the confocal microscope (Zeiss LSM710, Jena, Germany) (Excitations/emissions are 488/517).

\section{Penetration through multicellular tumor spheroids.}

MDA-MB-231 cells were seeded at $1 \times 10^{4}$ cells/well and cultured for 5-7 days to obtain 3D multicellular tumor spheroids of $400-500 \mu \mathrm{m}$ in diameter. The spheroids were carefully transferred to glass-bottom dishes, where UIO-Pimo and UIO-B $(10 \mu \mathrm{M})$ were added and incubated for $3 \mathrm{~h}$. After washing with PBS, Z-stack images of the spheroids were acquired at $10 \mu \mathrm{m}$ intervals using a confocal microscope, and subsequently 3D-rendered images were constructed using ZEN microscopy software.

\section{Cellular uptake.}

MDA-MB-231 cells were seeded in 6-well plates at a density of $1 \times 10^{5}$ cells per well. After incubation of UIO, UIO-B and UIO-Pimo for $3 \mathrm{~h}$ (the concentration of [Fe] was $10 \mu \mathrm{g} / \mathrm{ml}$ ), the cells were washed with PBS and then trypsinized and centrifuged to the bottom of the $0.5 \mathrm{~mL}$ tube. The concentration of intracellular [Fe] was determined by ICP-OES.

To investigate the internalized nanoparticles in cells by TEM, MDA-MB-231 cells were seeded in 6-well plate at a density of $1 \times 10^{5}$ cells per well and treated under the same conditions. Then the cells were washed with PBS twice carefully and fixed with $2.5 \%$ glutaraldehyde in $0.1 \mathrm{M}$ cacodylate buffer $(\mathrm{pH}$ 7.4) and then washed and post fixed with $1 \%$ osmium tetroxide. After being 
rinsed with deionized water, samples were dehydrated through an ethanol series to $100 \%$ ethanol and then infiltrated with Eponate 12 resin (Ted Pella Inc., Redding, CA) overnight. After additional infiltration, samples were placed in a labeled Beem capsule and polymerized at $60{ }^{\circ} \mathrm{C}$ in an oven. Ultrathin sections were cut at $70-80 \mathrm{~nm}$ thickness on a Leica UltraCut Sultramicrotome (Leica Microsystems Inc., Buffalo Grove, IL). Grids with ultrathin sections were stained with 5\% uranyl acetate and 2\% lead citrate. Ultrathin sections were imaged on a Ht-7700 TEM (JEOL Ltd., Tokyo, Japan).

\section{Magnetic resonance imaging.}

MDA-MB-231 cells were seeded in $10 \mathrm{~cm}$ culture dishes and exposed with UIO, UIO-B, UIO-Pimo with the same iron concentration of $10 \mu \mathrm{g} / \mathrm{ml}$ for $3 \mathrm{~h}$. After exposure, cells were washed three times with PBS and then trypsinized and centrifuged to the bottom of the $0.5 \mathrm{~mL}$ tube for MR imaging. MR images were acquired using a 7.0 T MR imaging machine (BioSpec 7.0 70/20, Bruker, Germany). MR images were obtained using a T2-Turbo RARE sequence with parameters as follows: $\mathrm{TR}=3025 \mathrm{~ms}, \mathrm{TE}=40 \mathrm{~ms}$, field of view $=40 \times 40 \mathrm{~mm}$, matrix size $=200$ $\times 200$, number of slices $=26$, slice thickness $=1 \mathrm{~mm}$, flip angle $=90^{\circ}$.

For in vivo MR imaging, Balb/c-bearing 4T1 murine breast cancer tumors were intravenously injected with UIO-B, UIO-Pimo at a concentration of $20 \mathrm{mg}$ Fe/kg. MR imaging was conducted through a 7.0 T MRI scanner equipped with a mouse body coil. The T2-weighted images were acquired at $0.5,1,2,4,6,8$ and $24 \mathrm{~h}$. Images obtained before injection were used as controls. MR images were acquired using a T2-Turbo RARE sequence with parameters as follows: TR $=4653$ $\mathrm{ms}, \mathrm{TE}=40 \mathrm{~ms}$, field of view $=35 \times 35 \mathrm{~mm}$, matrix size $=200 \times 200$, number of slices $=40$, slice thickness $=1 \mathrm{~mm}$, flip angle $=90^{\circ}, \mathrm{NEX}=3.0$.

\section{Nanoparticle biodistribution in vivo.}

To better quantify the tumor accumulation of UIO-Pimo and UIO-B, we analyzed the collected tumors using ex vivo histological examinations with a confocal microscope, Prussian blue iron staining and NBD fluorescence imaging. The tumors and main organs were collected at $4 \mathrm{~h}$ after injection of UIO-Pimo (or UIO-B). The tissue samples were embedded in OCT and frozen in 
liquid nitrogen. After being cryo-stated into $8 \mu \mathrm{m}$ slices, the tumor sections were stained with DAPI. Quantitative colocalization analysis of NBD green fluorescence and HIF-1 $\alpha$ red fluorescence was determined with a confocal microscope. Prussian blue staining to confirm the localization of Fe in tissue sections. All image-based quantitative analyses were performed using Image Pro Plus (NIH).

\section{Immunofluorescence staining.}

Tumors were collected from the mice and tumor sections were cut using a cryotome, mounted on slides and stained with HIF-1 $\alpha$ primary antibody overnight at $4{ }^{\circ} \mathrm{C}$ following the manufacturer's instructions. Following the addition of fluorescently labeled secondary antibodies Cy3-labeled goat anti-rabbit IgG (Servicebio, cat. no. GB21303), the slides were analyzed with a confocal microscope (Zeiss LSM 710). All antibodies used in the experiments were diluted 200 times.

\section{MRI difference value method.}

To eliminate the individual difference, the average $T_{2}$ value of tumor tissue before injection of nanoparticles from one mouse was chosen as the reference. The area whose relaxation time reduced more than a certain value (at $8 \mathrm{~h}$ after the i.v. injection of UIO-Pimo) is defined as the hypoxic region and the greater the change, the more hypoxia. The certain value was called the difference value. 


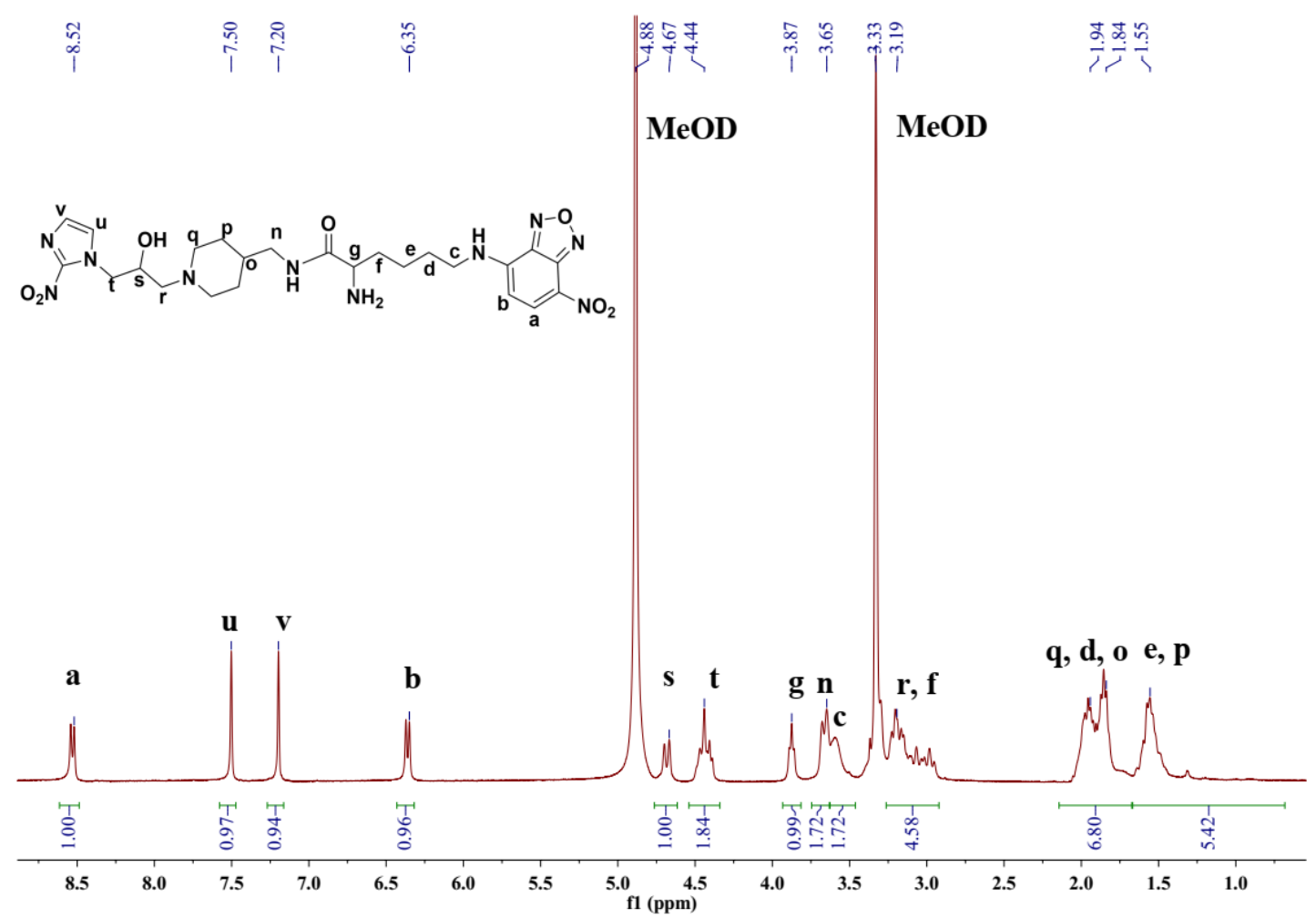

Figure S1. ${ }^{1} \mathrm{H}$ NMR spectrum of compound 5.

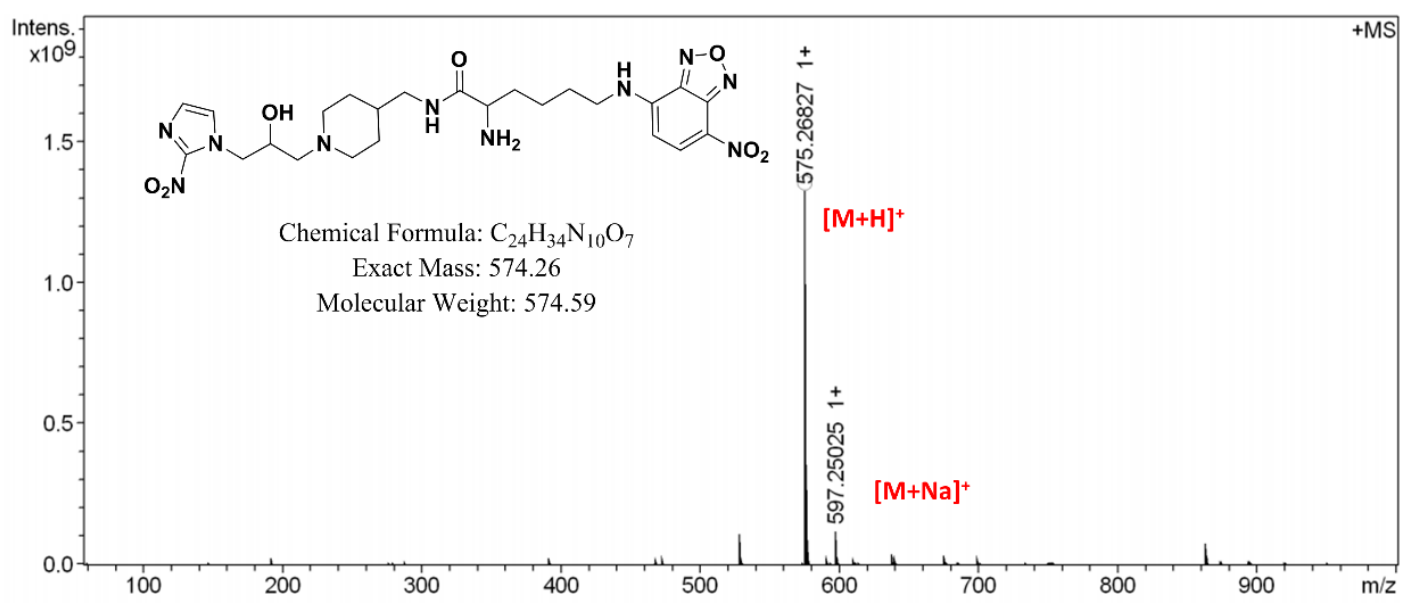

Figure S2. HR-ESI/MS spectrum of compound 5. 


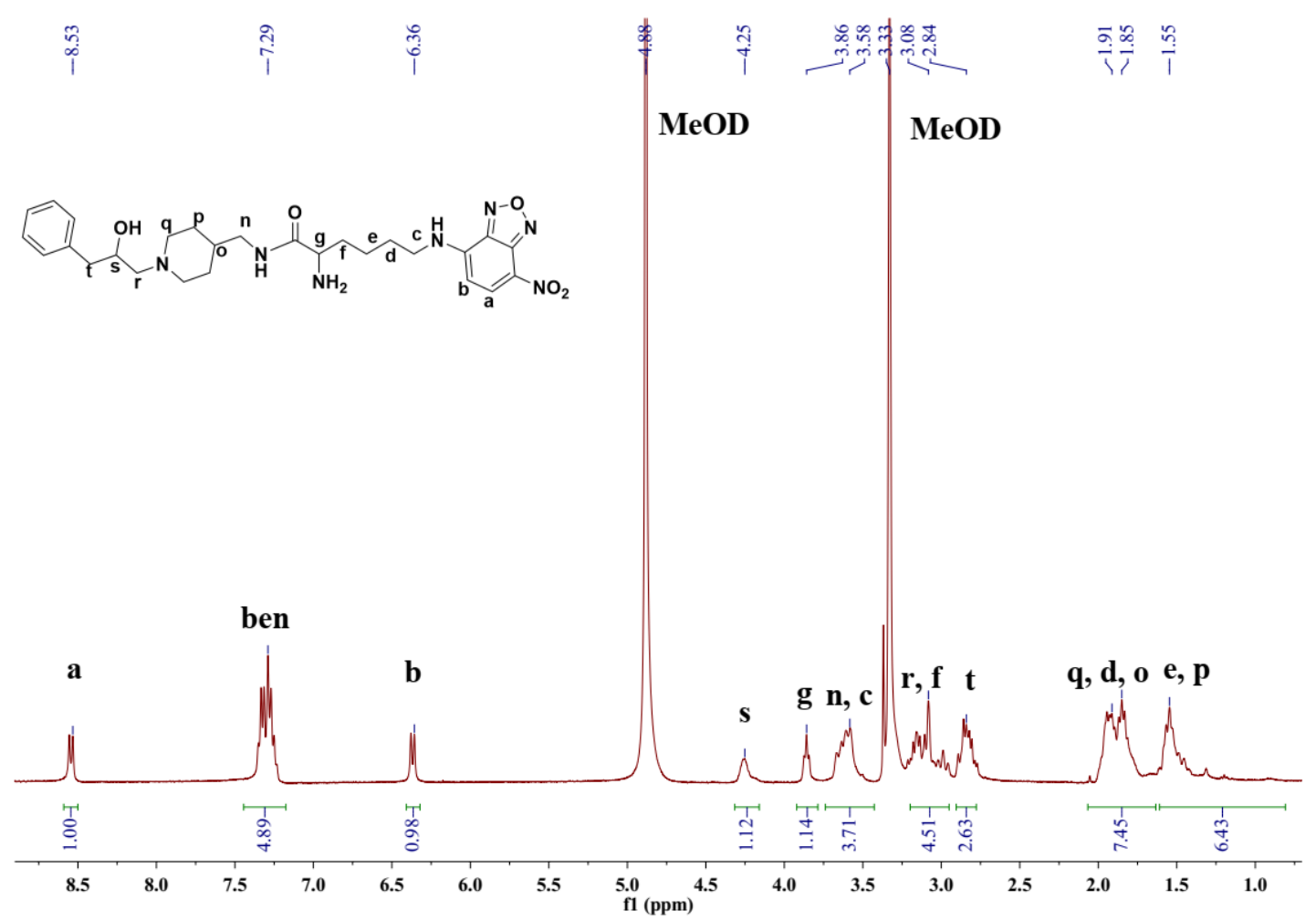

Figure S3. ${ }^{1} \mathrm{H}$ NMR spectrum of compound 8.

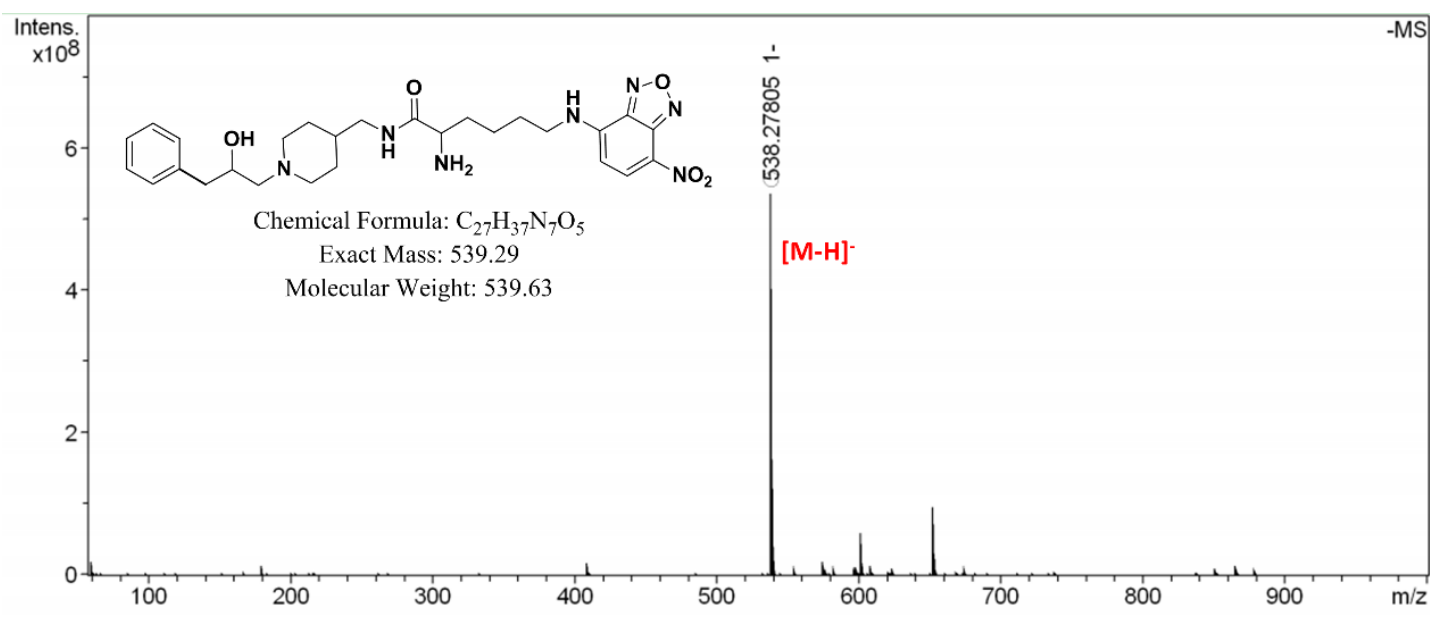

Figure S4. HR-ESI/MS spectrum of compound 8. 

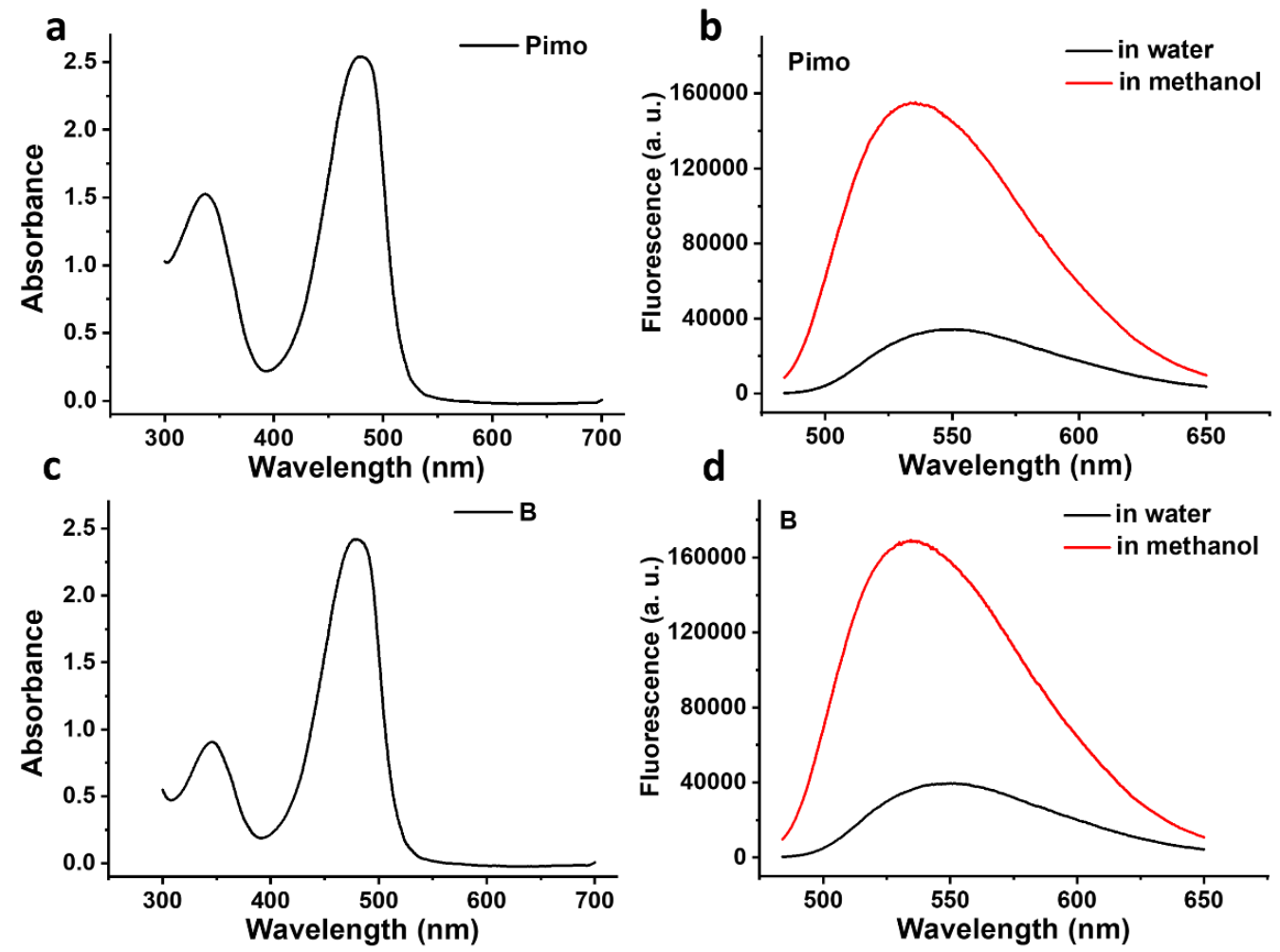

Figure S5. UV-vis spectra of Pimo (a) and B (c); fluorescence spectra of Pimo (b) and B (d) (Ex: $480 \mathrm{~nm}$; concentration: $50 \mu \mathrm{M}$ ). The absorption peak at $330 \mathrm{~nm}$ is due to the nitro group in pimonidazole and NBD and that at $464 \mathrm{~nm}$ owns to the characteristic peak of NBD. The fluorescence intensity of Pimo and B in methanol were stronger than that in water revealed that NBD could become brighter in hydrophobic condition.

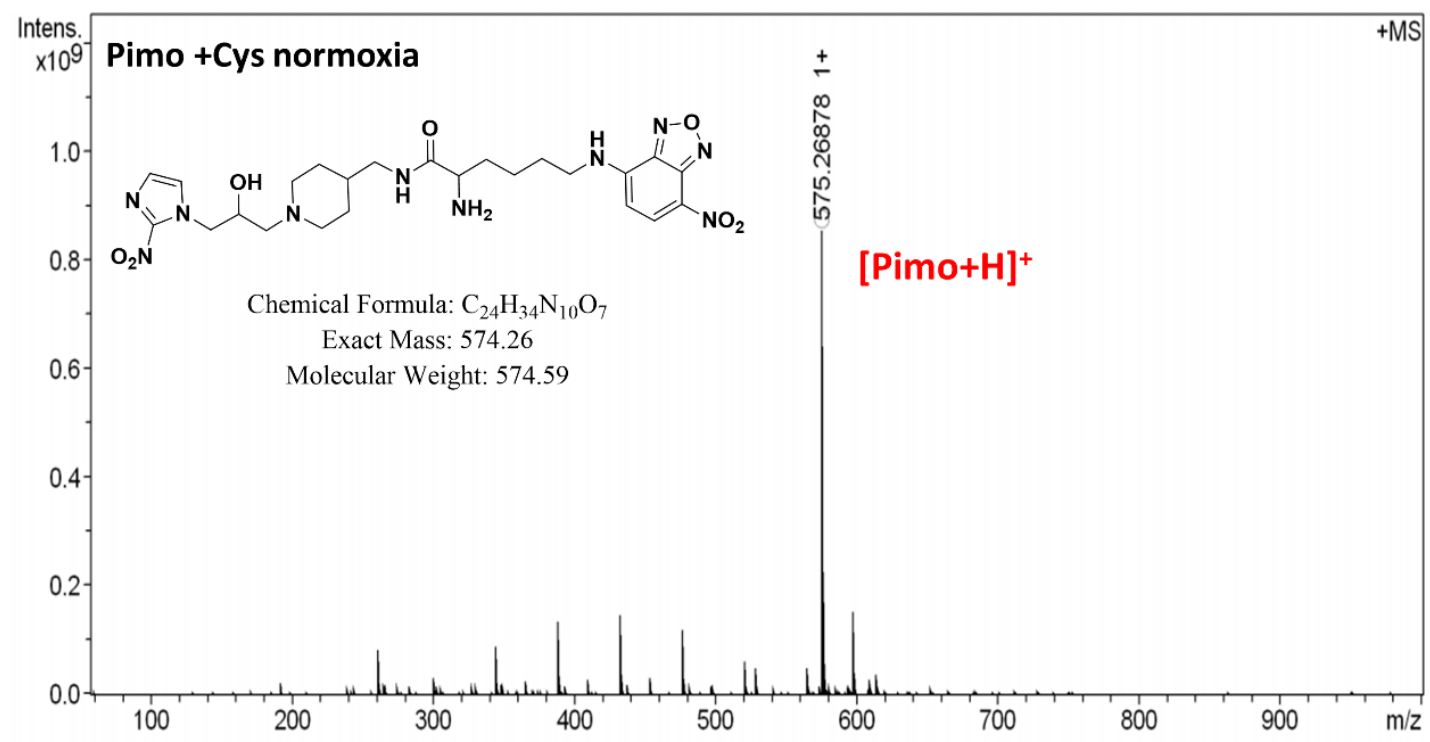

Figure S6. HR-ESI/MS spectrum of HPLC peak at 7.15 min in Figure 1f (Pimo + Cys: normoxia). 


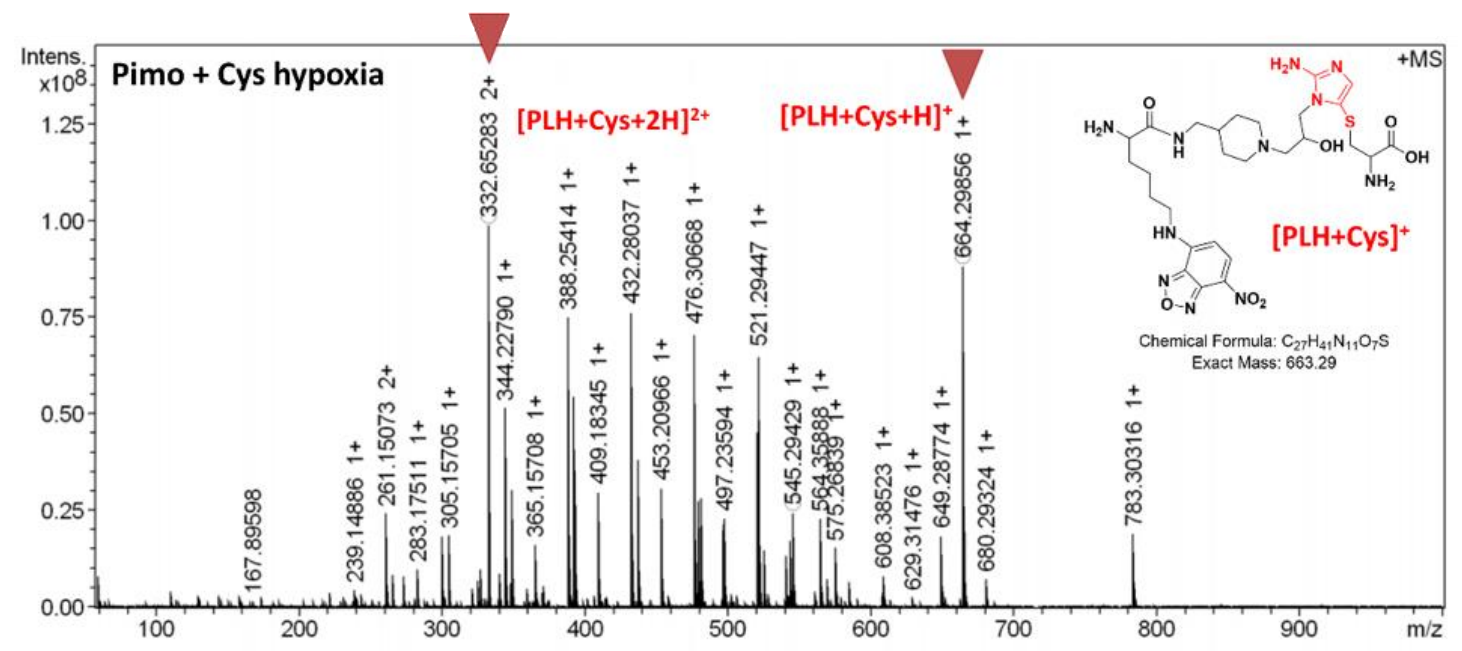

Figure S7. HR-ESI/MS spectrum of HPLC peak at 3.75 min in Figure 1g (Pimo + Cys: hypoxia).
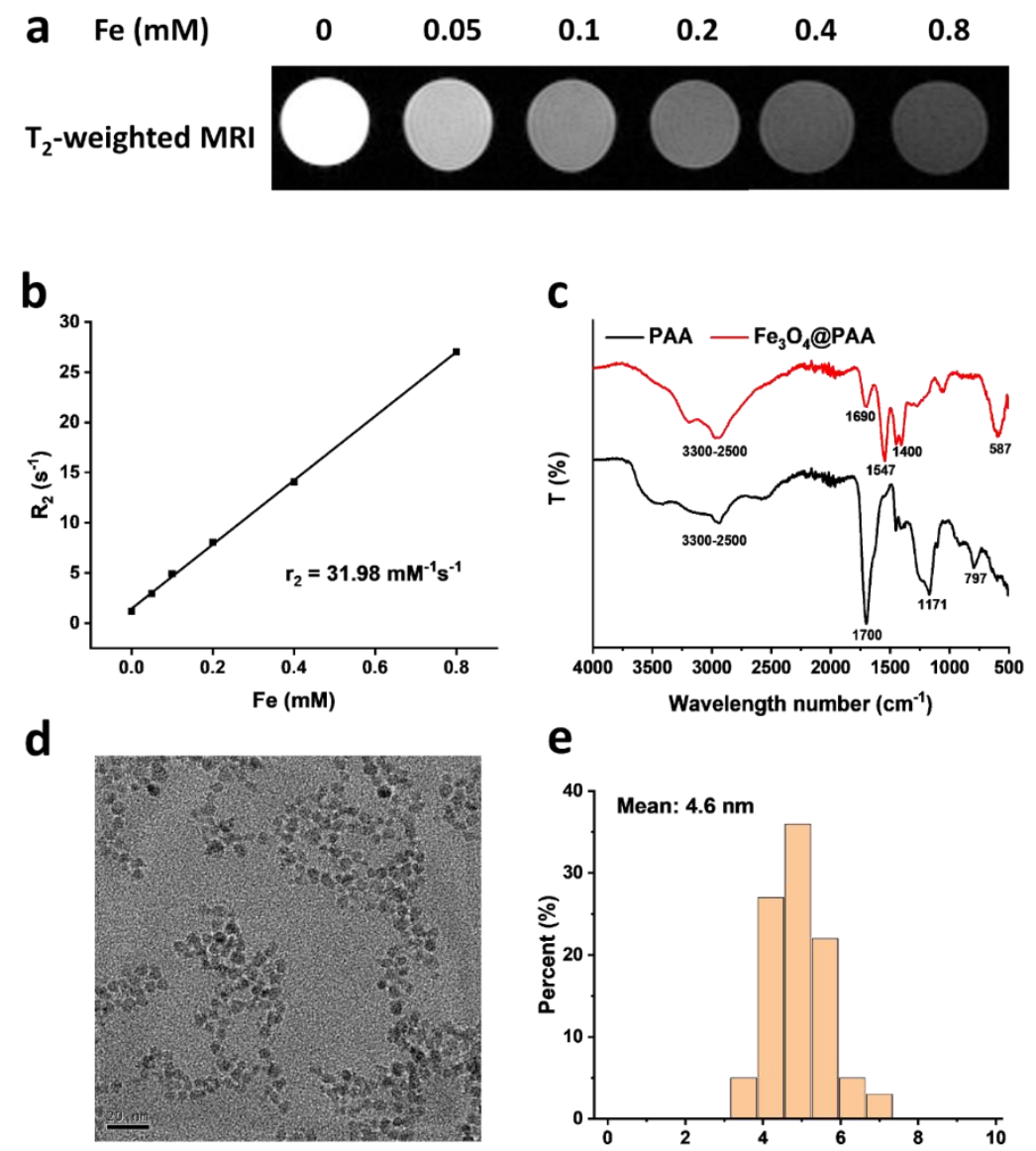

e

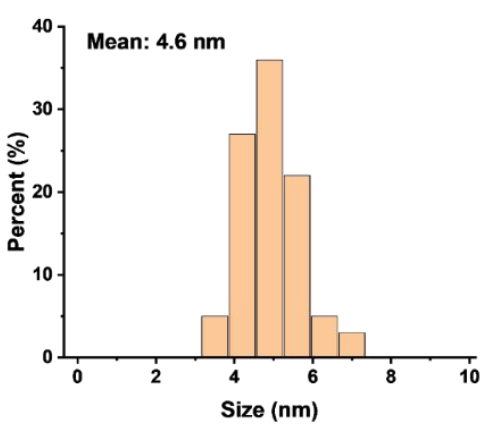

Figure S8. MRI phantom images of UIO with different iron concentrations (a); plot of relaxation value and iron concentration (b); FTIR spectra of PAA and $\mathrm{Fe}_{3} \mathrm{O}_{4} @$ PAA (UIO) (c); TEM images (d) and size distribution (e) of UIO. (a) and (b) indicates the good $\mathrm{T}_{2}$ weighted MRI properties of UIO. The relaxation value has a linear relationship with iron concentration helping us to know the concentration of UIO from the result of $\mathrm{T}_{2}$ mapping. The presence of feature peaks of PAA in UIO illustrates the successful modification of PAA on the surface of iron oxide nanoparticles (c). (d) and (e) demonstrates the uniform of UIO and the average size is $4.6 \mathrm{~nm}$. 

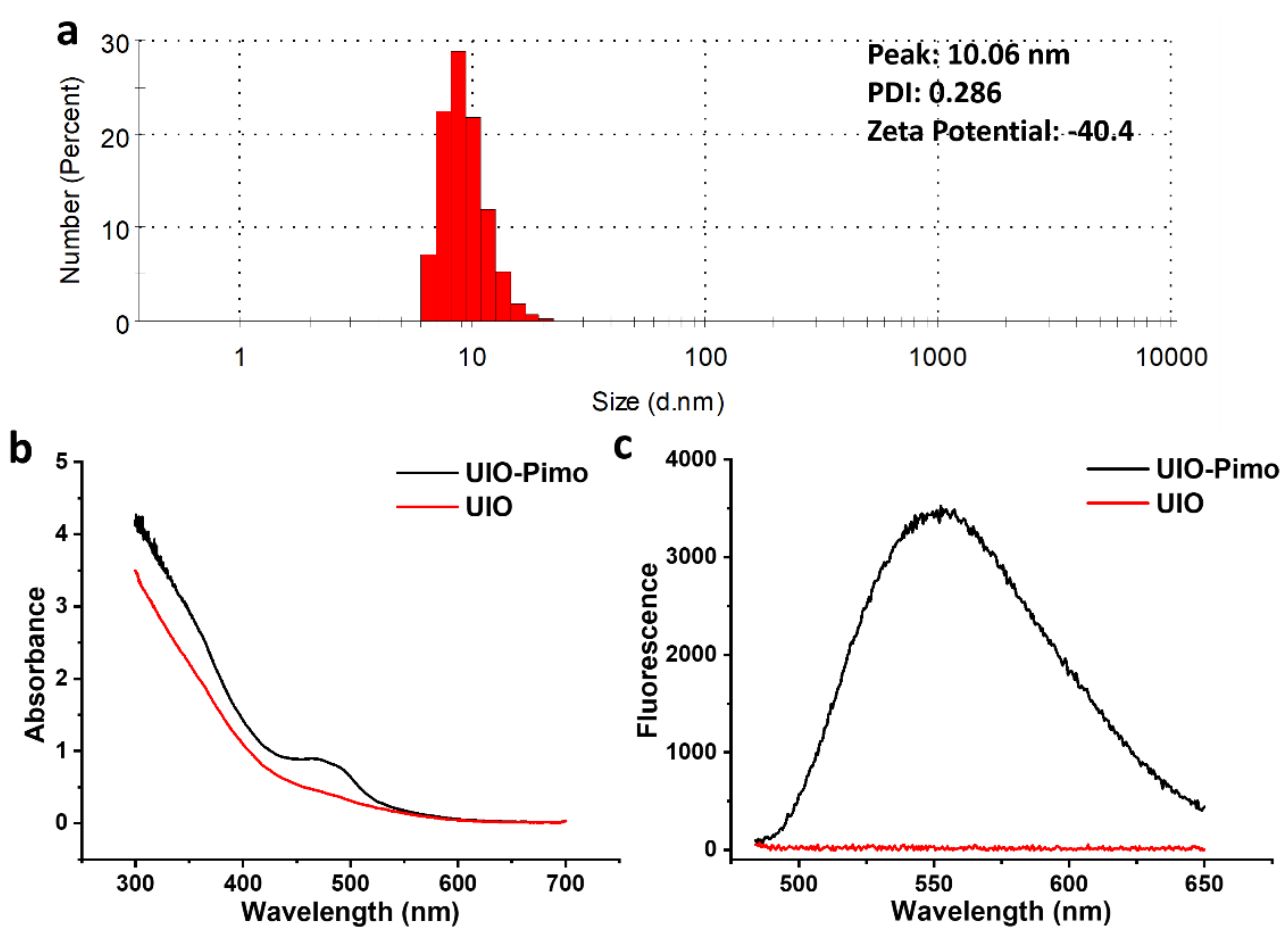

Figure S9. DLS data (a), absorption spectrum (NBD: $50 \mu \mathrm{M}$ ) (b) and fluorescence spectrum (NBD: $300 \mu \mathrm{M}$ ) (c) of UIO-Pimo. The appearance of absorption peak at about $480 \mathrm{~nm}$ and the fluorescence signal $(560 \mathrm{~nm})$ indicated the successful modification of Pimo.
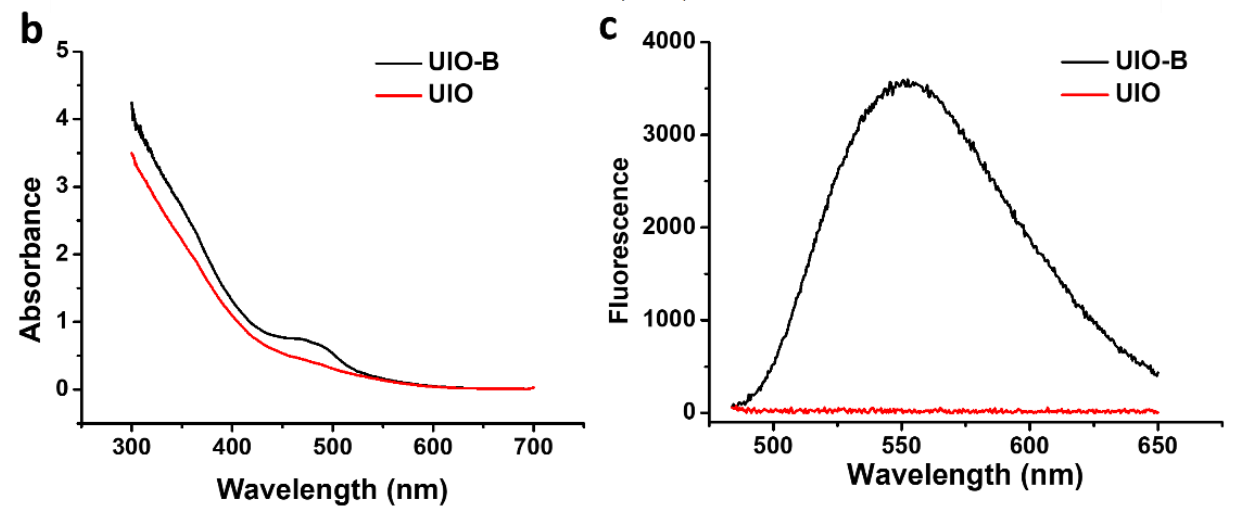

Figure S10. DLS data (A), absorption spectrum (NBD: $50 \mu \mathrm{M})(B)$ and fluorescence spectrum (NBD: $300 \mu \mathrm{M})(\mathrm{C})$ of UIO-B. The appearance of absorption peak at about $480 \mathrm{~nm}$ and the fluorescence signal $(560 \mathrm{~nm})$ indicated the successful modification of B. 


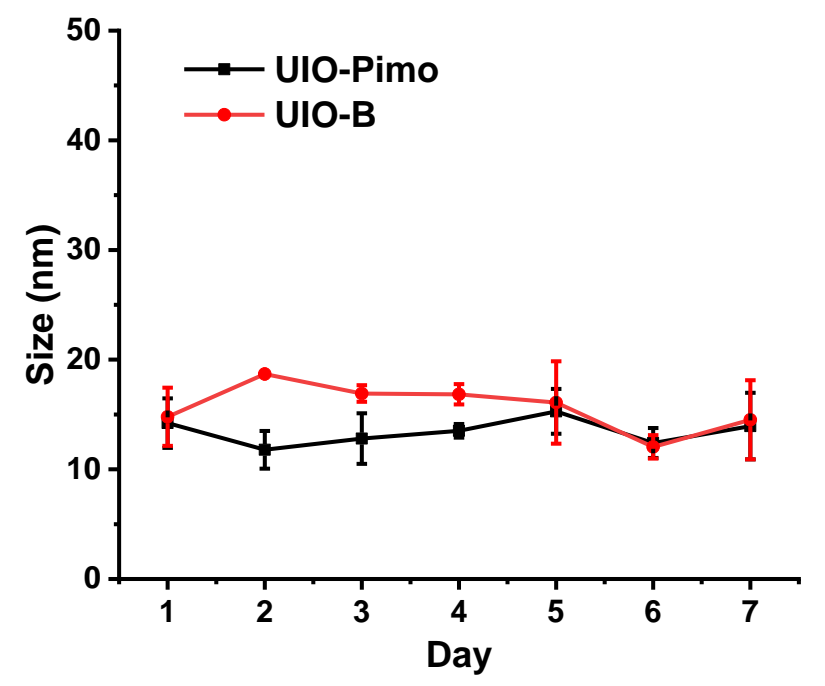

Figure S11. Stability of UIO-Pimo and UIO-B in PBS.
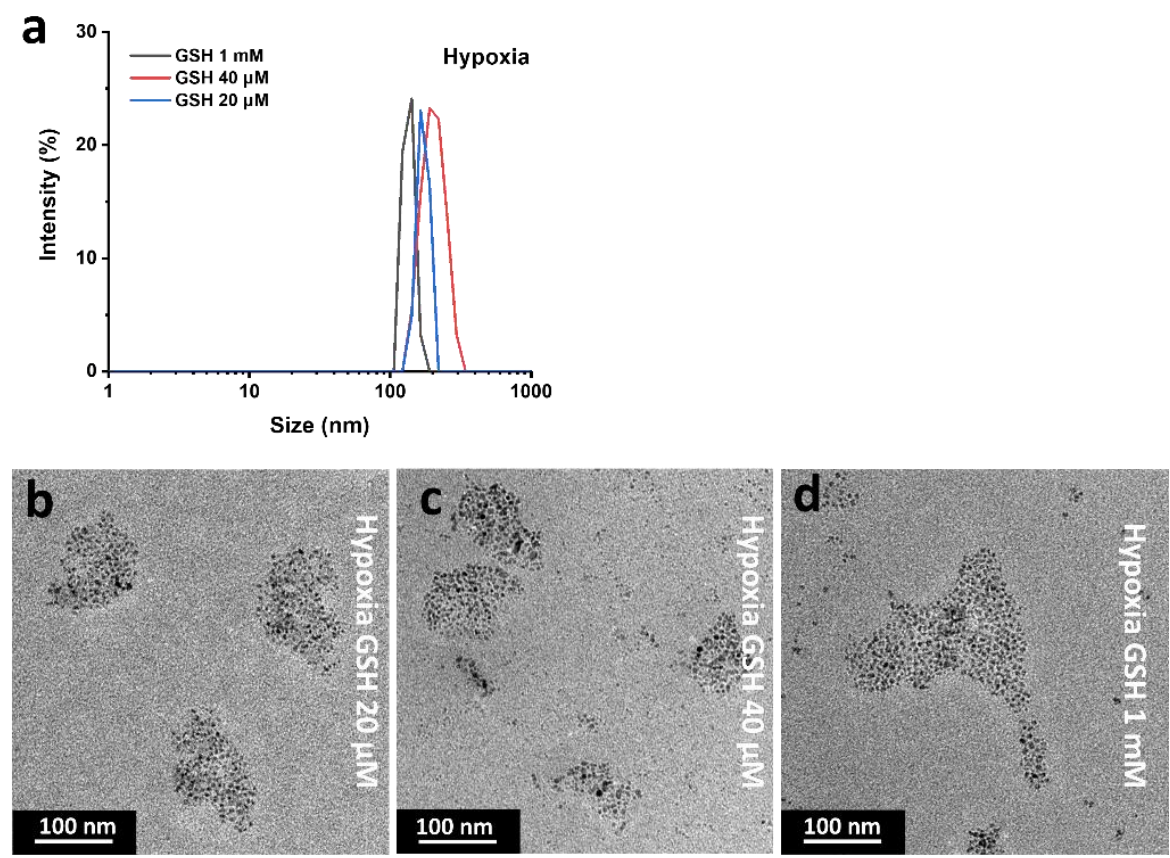

Figure S12. The influence of GSH on the hypoxia-triggered self-assembly of UIO-Pimo. Hydrodynamic size (a) of solutions in figure S14b-d at $25^{\circ} \mathrm{C}$. TEM images of UIO-Pimo treated under hypoxia with the presence of GSH, NADPH and reductase at $37^{\circ} \mathrm{C}$ for $1 \mathrm{~h}$, (b) GSH $20 \mu \mathrm{M}$, (c) GSH $40 \mu \mathrm{M}$ and (d) GSH $1 \mathrm{mM}$. 


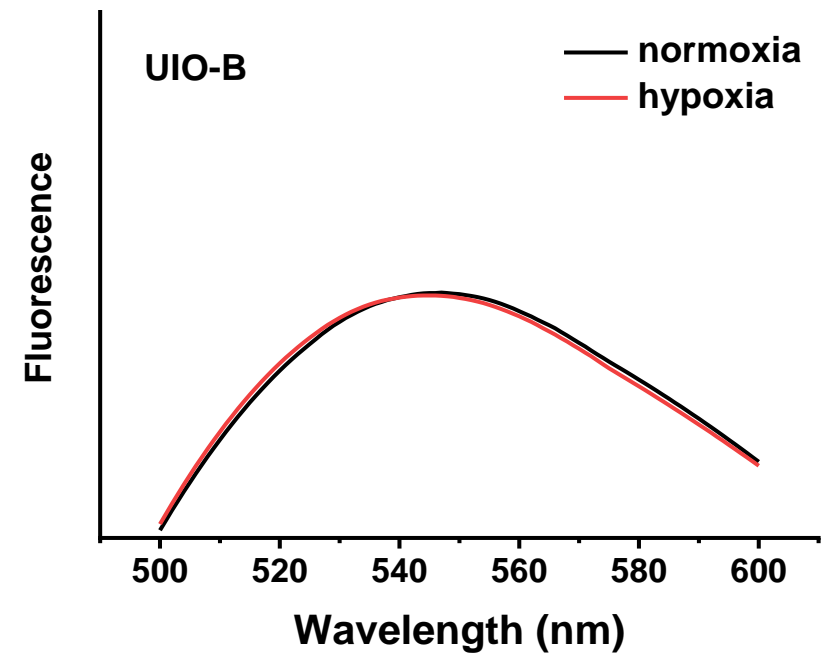

Figure S13. Fluorescence intensity (per mM NBD) of UIO-B solution under hypoxia and normoxia.
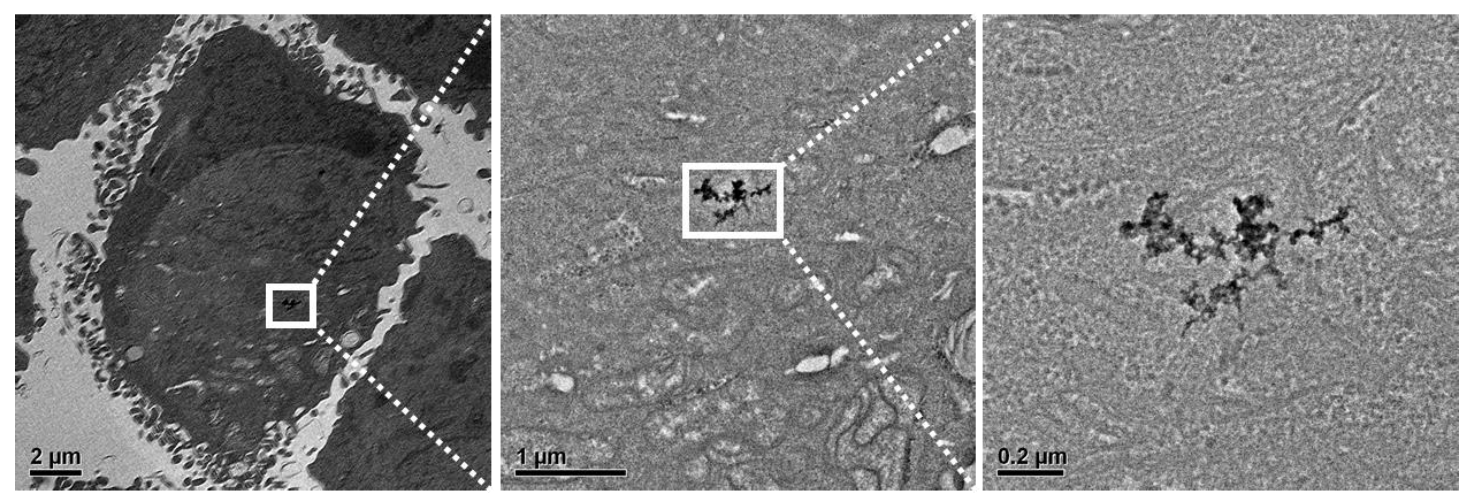

Figure S14. TEM images of MDA-MB-231 cells incubated with UIO-Pimo under hypoxia $(0.1 \%$ $\mathrm{O}_{2}$ ).
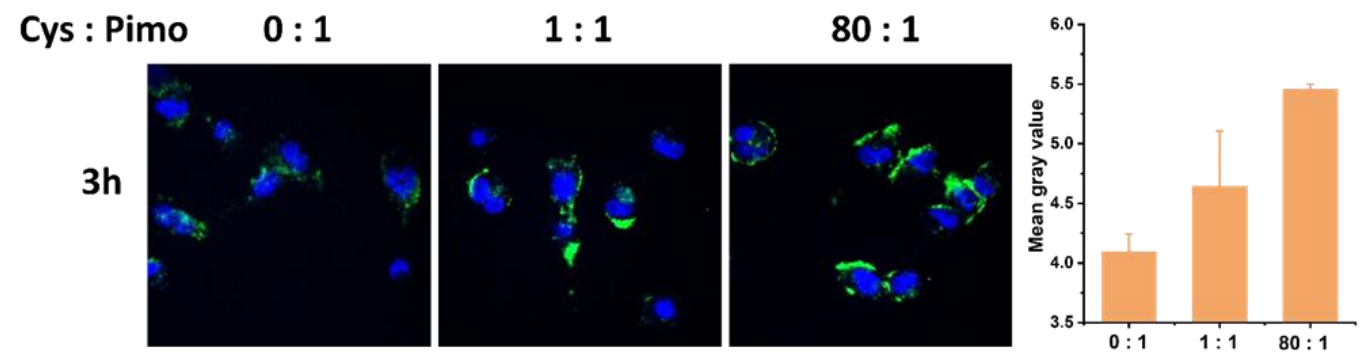

Figure S15. The effect of different input ratio of cysteine and Pimo to the fluorescence imaging of UIO-Pimo. 


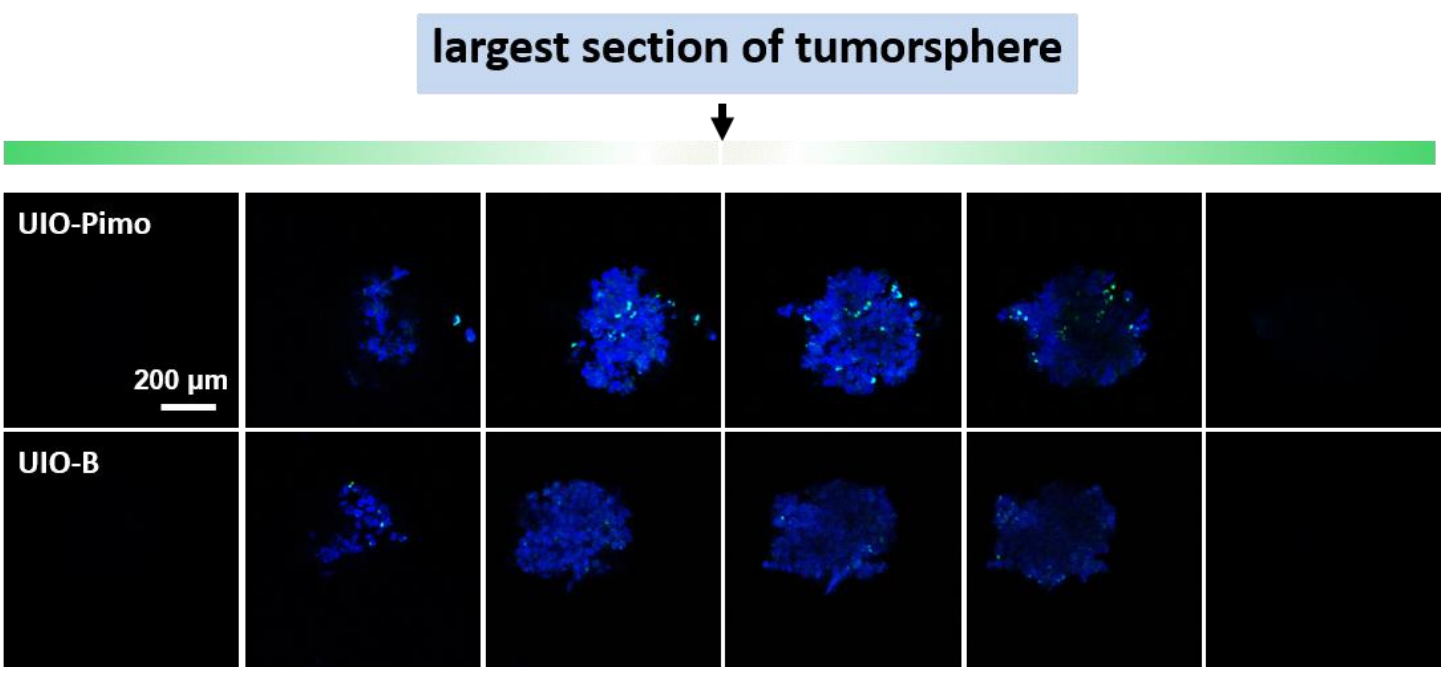

Figure S16. Penetration of UIO-Pimo and UIO-B by the 3D tumor-spheroids model.

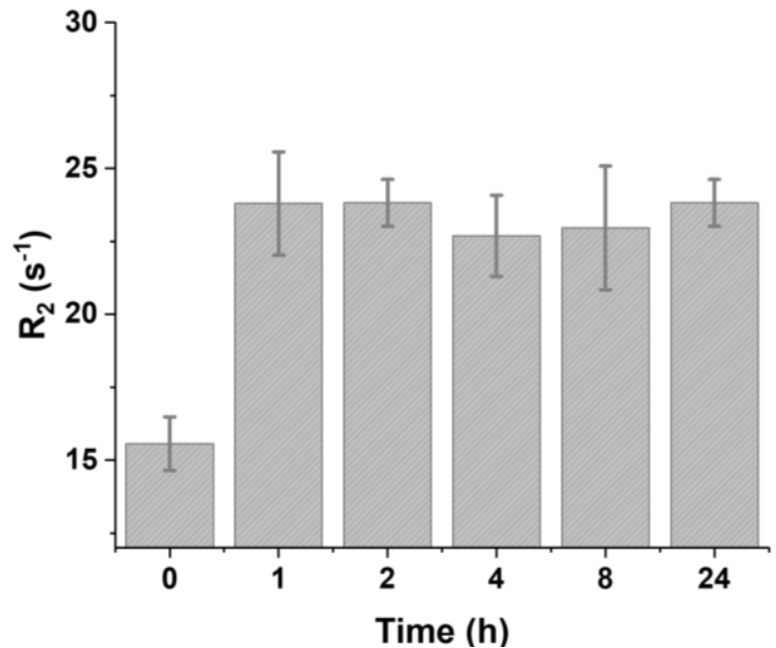

Figure S17. Relaxation values of UIO-Pimo under hypoxia different times with the appearance of NADPH and reductase. The relaxation value didn't change significantly after $1 \mathrm{~h}$, indicating that this hypoxia reaction is finished at $1 \mathrm{~h}$. Therefore, we use $1 \mathrm{~h}$ as the optimum reaction time with the self-assemble measure experiments. 


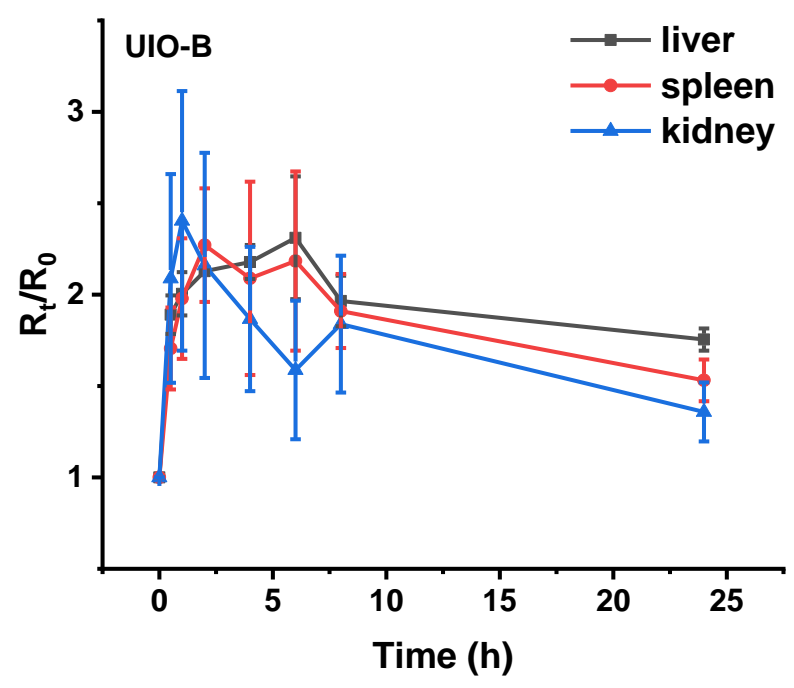

Figure S18. Signal intensity of liver, spleen and kidney after the injection of UIO-B (n $=3$ ).

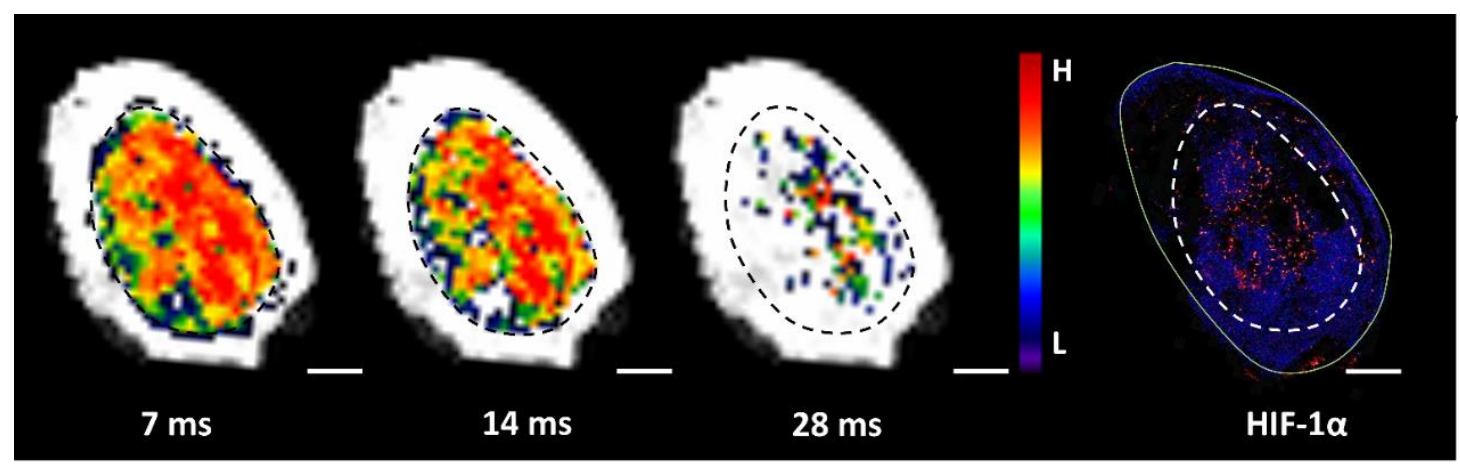

Figure S19. The effect of different MRI difference values. 
a

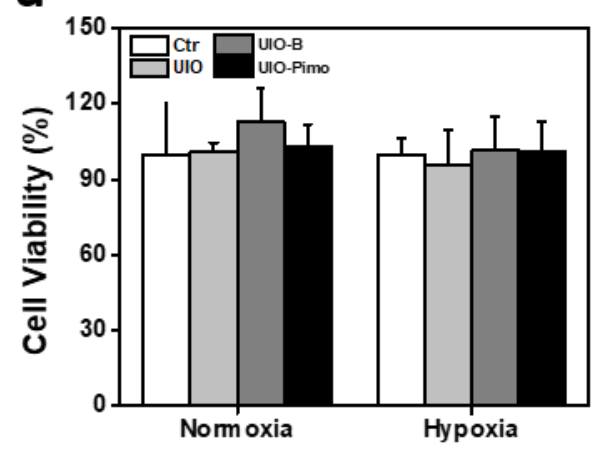

C

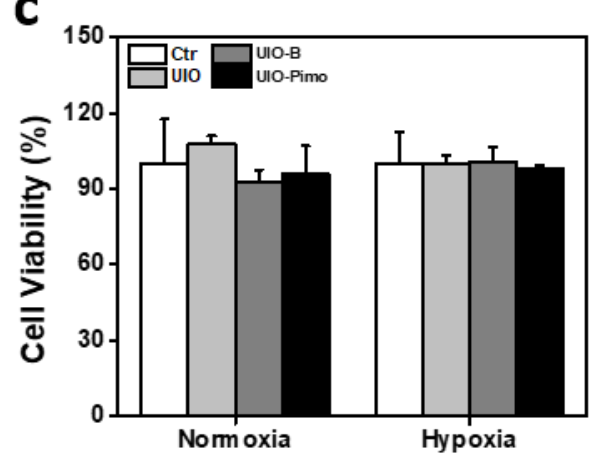

b
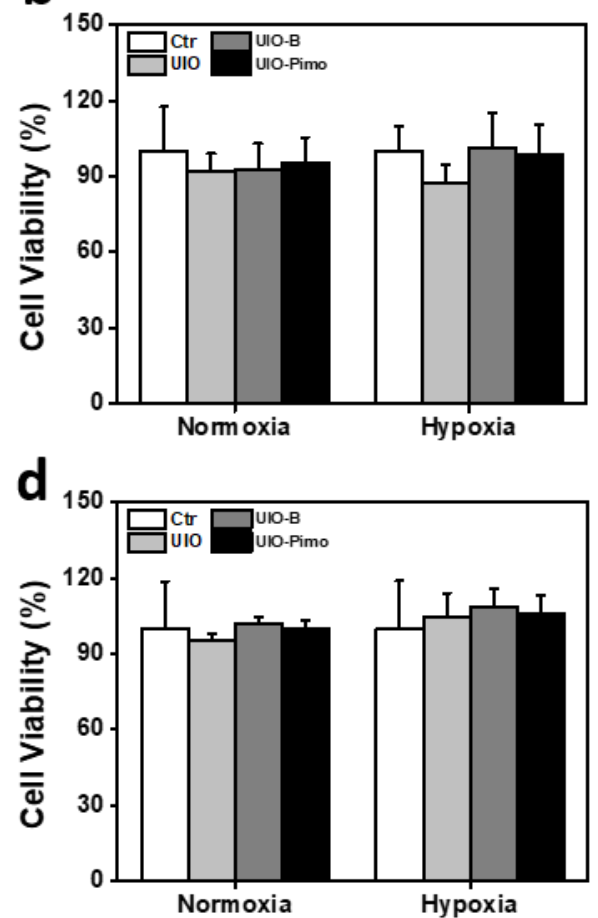

Figure S20. Cell viability of (a) MDA-MB-231, (b) B16, (c) 4T1 and (d) MCF-7 cells incubated with UIO-B and UIO-Pimo for $24 \mathrm{~h}$ under normoxia $\left(21 \% \mathrm{O}_{2}\right)$ and hypoxia $\left(0.1 \% \mathrm{O}_{2}\right)$. No obvious changes are observed, demonstrating the safety of these three iron oxide nanoparticles. 


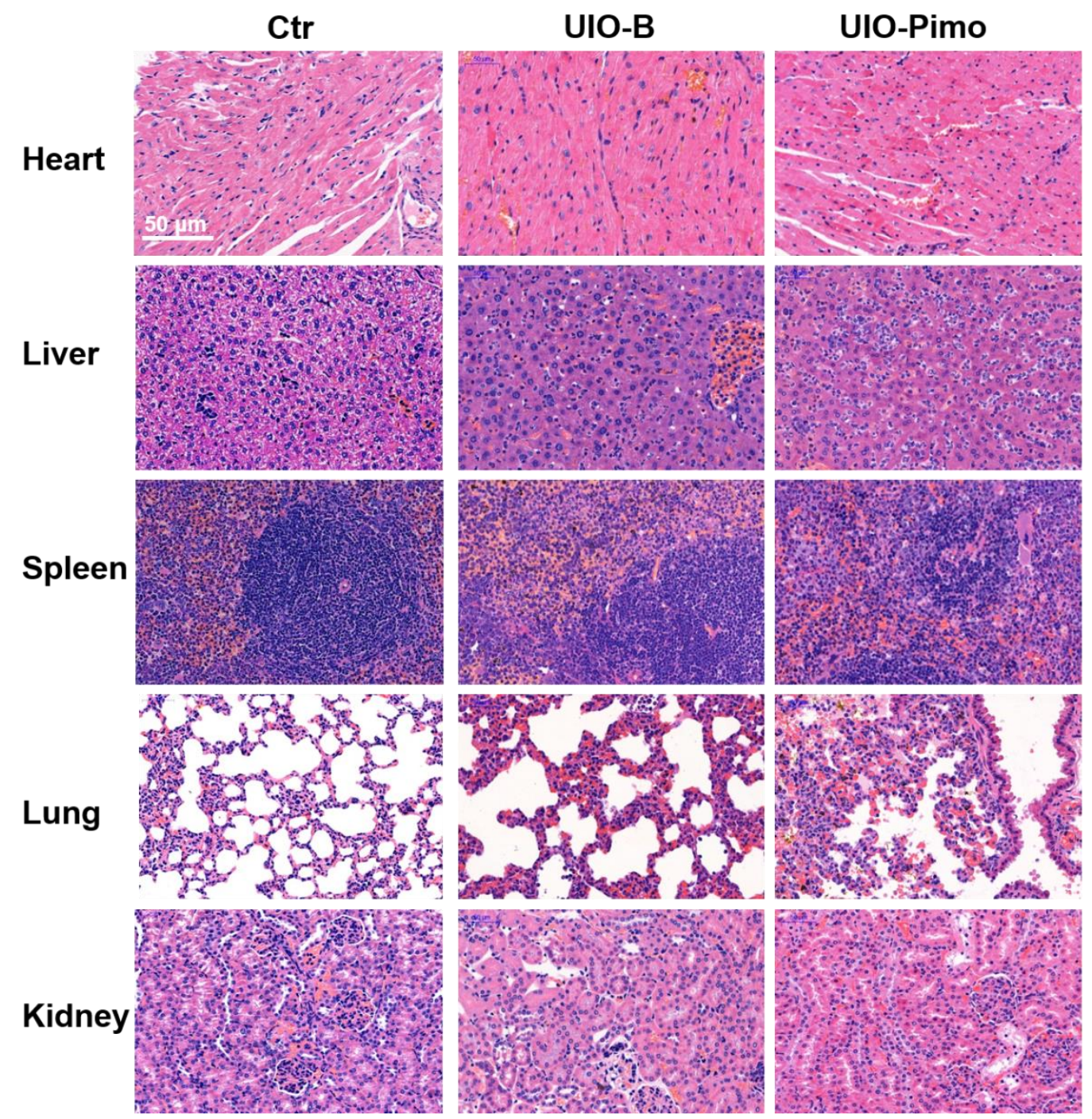

Figure S21. H\&E staining of tissue from selected organs harvested at $48 \mathrm{~h}$ for normal nude mouse after the injection of UIO, UIO-B and UIO-Pimo $20 \mathrm{mg}$ Fe/kg. These images indicate that no acute inflammatory reactions and pathological changes within UIO, UIO-B and UIO-Pimo groups and all of these three nanoparticles are safe at the dosage of $20 \mathrm{mg} \mathrm{Fe} / \mathrm{kg}$.

\section{REFERENCES}

1. Evans, S. M.; Kim, K.; Moore, C. E.; Uddin, M. I.; Capozzi, M. E.; Craft, J. R.; Sulikowski, G. A.; Jayagopal, A. Molecular Probes for Imaging of Hypoxia in the Retina. Bioconjugate Chem. 2014, 25, 2030.

2. Li, Z.; Tan, B.; Allix, M.; Cooper, A. I.; Rosseinsky, M. J. Direct Coprecipitation Route to Monodisperse Dual Functionalized Magnetic Iron Oxide Nanocrystals Without Size Selection. Small 2008, 4, 231.

3. Li, F.; Li, Y.; Yang, X.; Han, X.; Jiao, Y.; Wei, T.; Yang, D.; Xu, H.; Nie, G. Highly Fluorescent Chiral N-S-Doped Carbon Dots from Cysteine: Affecting Cellular Energy Metabolism. Angew. Chem. Int. Edit. 2018, 57, 2377. 